\title{
An approach of understanding acid volcanics and tuffaceous volcaniclastics from field studies: A case from Tadpatri Formation, Proterozoic Cuddapah basin, Andhra Pradesh, India
}

\author{
Sukanta Goswami ${ }^{1, *}$, P K Upadhyay ${ }^{1}$, Sangeeta Bhagat ${ }^{1}$, \\ Syed Zakaulla $^{1}$, A K Bhatt ${ }^{1}$, V Natarajan ${ }^{1}$ and Sukanta Dey ${ }^{2}$ \\ ${ }^{1}$ Atomic Minerals Directorate for Exploration and Research, Bengaluru 560 072, India. \\ ${ }^{2}$ Indian Institute of Technology (ISM), Dhanbad 826 004, India. \\ *Corresponding author. e-mail: sukantagoswami.amd@gov.in
}

MS received 27 January 2017; revised 12 July 2017; accepted 13 July 2017; published online 6 March 2018

The lower stratigraphic part of the Cuddapah basin is marked by mafic and felsic volcanism. Tadpatri Formation consists of a greater variety of rock types due to bimodal volcanism in the upper part. Presence of bimodal volcanism is an indication of continental rift setting. Various genetic processes involved in the formation of such volcanic sequence result in original textures which are classified into volcaniclastic and coherent categories. Detailed and systematic field works in Tadpatri-Tonduru transect of SW Cuddapah basin have provided information on the physical processes producing this diversity of rock types. Felsic volcanism is manifested here with features as finger print of past rhyolite-dacite eruptions. Acid volcanics, tuffs and associated shale of Tadpatri Formation are studied and mapped in the field. With supporting subordinate studies on geochemistry, mineralogy and petrogenesis of the volcanics to validate field features accurately, it is understood that volcanism was associated with rifting and shallow marine environmental condition. Four facies (i.e., surge, flow, fall and resedimented volcaniclastic) are demarcated to describe stratigraphic units and volcanic history of the mapped area. The present contribution focuses on the fundamental characterization and categorization of field-based features diagnostic of silica-rich volcanic activities in the Tadpatri Formation.

Keywords. Acid volcanics; Cuddapah basin; Tadpatri Formation; tuff.

\section{Introduction}

The detailed study of the mafic emplacements over Vempalle and Tadpatri Formations have brought out important information on age relationships, tectonics, magma evolution and other geochemical characterisations (Chatterjee and Bhattacharji 2001; Sesha Sai 2011; Chakraborty et al. 2016).
However, acid volcanics are not addressed in detail so far. The volcanic facies study in this context has provided information on facies characteristics evident at outcrop scale in the field, such as structures, internal organisation and geometry. After having the idea on facies characters, interpretation is attempted for genetic aspects to have information on eruption and emplacement 
processes for primary volcanic and volcaniclastic deposits and on subsequent erosion, transport and redepositional processes for resedimented and volcanogenic sedimentary deposits. The textures in these volcanic rocks are divided on the basis of timing as: (1) Original textures by eruption and emplacement processes; (2) Modified original texture by syn-volcanic processes like oxidation, degassing, hydration, vapour-phase alteration, high-temperature devitrification, and hydrothermal alteration; (3) Textures formed due to modification by post-volcanic processes like hydration, devitrification, hydrothermal alteration, diagenesis, metamorphism, deformation and weathering. Since the area consists of volcaniclastics and tuffaceous shale and non-volcanic sediments, from a methodological point of view, studies and interpretations of volcaniclastic rocks are almost similar to those performed on clastic non-volcanic sediments. However, there are characteristic differences that make this volcaniclastic study complicated but interesting. Such differences are taken into account while defining the lithofacies categories of the area.

The field geologists working for the purpose of general mapping in such terrains with ancient volcanism can use this field-based paper as a guide for interpreting volcanic processes and the resulting deposits and resedimentation of volcaniclastics. The objective of the paper is to introduce basic field volcanology in Tadpatri Formation. This paper encompassing volcanic facies analysis is one of the main goals of studying volcanic rocks in the field and this has been utilised for palaeoenvironmental reconstructions.

\section{General geology}

Cuddapah Basin, one of the largest Proterozoic basins in India, consists of sedimentary and associated volcanic rocks of about $12 \mathrm{~km}$ thickness, ranging in age from late Paleoproterozoic to Neoproterozoic (Nagaraja Rao et al. 1987; Bhaskar Rao et al. 1995; Ramam and Murty 1997; Zachariah et al. 1999). A detail description of stratigraphy, structure, igneous activities, mineral potentiality and basin evolution is summarised by Nagaraja Rao et al. (1987). The stratigraphic sequence initiated by Gulcheru Quartzite, nonconformably overlying the Archaean granitoids and greenstone belts, is followed up by Vempalle Formation which together forms part of the Papaghni Group. Tadpatri Formation hosts argillaceous sediments with thin intercalated quartzite and volcanogenic sediments overlying the Pulivendula Quartzite in the Chitravati Group.

The importance of associated volcanic and volcanogenic rocks in compilation of geological record is apparent due to their characteristic chemistry, relatively fast accumulation and great variety that provide recognizable facies diversity for reconstructing not only the volcanic processes but also the past eruptive environment of volcanism. Nagaraja Rao et al. (1987) have given a detailed description of stratigraphy of the Tadpatri Formation which consists of shale with quartzite intercalations, shale with limestone/dolomite intercalations, shale with ash fall/flow and tuffs, shale with stromatolitic dolomite intercalations from bottom to top. The basic flows and sills are also present along with acid volcanics in the Tadpatri Formation. The tuffs are mainly acidic in composition. The area from Tadpatri to Tonduru is a NW-SE trending rectangular block (figure 1), where the lithounits are striking NW-SE and dipping around $10^{0}$ towards NE and basic flows are very common along the same trend. Parallel beds of acid and basic volcanic flow and volcaniclastic sediments and ash fall tuff beds are overlain by Gandikota Quartzite with gradational conformable contact along the Gandikota range (GSI 1981; Nagaraja Rao et al. 1987). The Tadpatri volcaniclastic sequence is often overlain by sub-horizontal quartzite beds of Banganapalle Formation of Kurnool Group with angular unconformity at above $500 \mathrm{~m} \mathrm{RL}$ as flat hill top capping in the study area.

\section{Volcanology of Tadpatri Formation}

Volcanic rocks that are significantly fragmented are important from a stratigraphic point of view and thus they are used to study palaeoenvironments. Bimodal volcanism is remarkable in the area. Mafic volcanism is well documented and more widely studied compared to felsic counterpart and thus felsic rocks are studied in detail. Evidences of fragmentation, a process which occurs when bubbles become over-pressured and burst, is noteworthy in the area. Stratigraphically, the study area consists of upper part of the Tadpatri Formation dominated by volcaniclastic rocks. Presence of coherent rocks (simply solidified from the melt) and volcaniclastic debris (formed through a wide range and combinations of different style of fragmentation, 


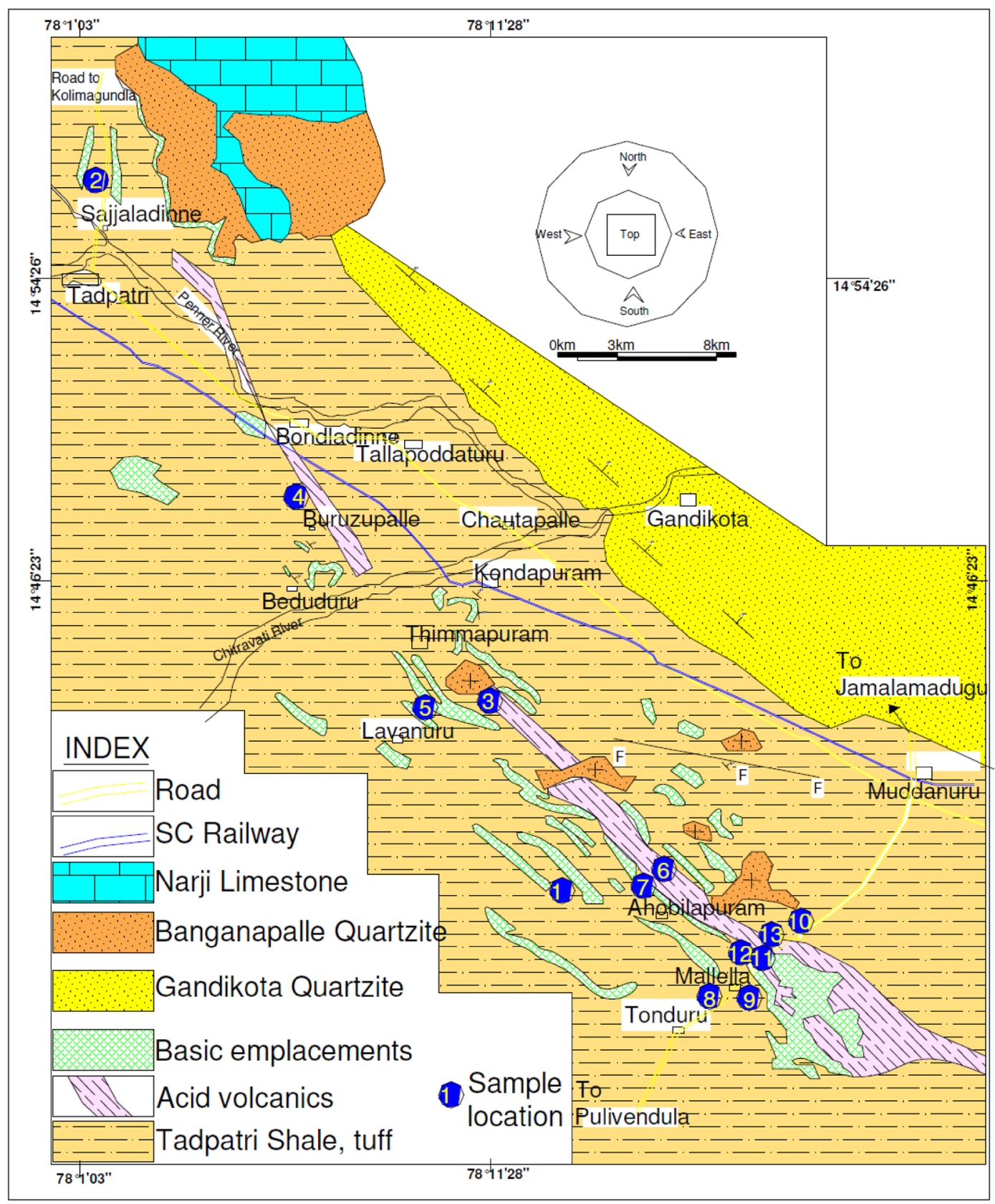

Figure 1. Geological map of the studied area from Tadpatri to Tonduru. The blue circular numbers represent sample locations.

transportation and deposition processes) in the upper part of the stratigraphic column is prominent. As far as bedding characteristics are concerned, massive or thinly laminated units and moderate to well-defined beds with different textural features carry important information about the transport mechanisms, such as physical aspects of flow including rheology and particle concentration. The pyroclastic materials within the Tadpatri Formation are noted mainly as lapilli $(2-10 \mathrm{~mm})$, ash $(<2 \mathrm{~mm})$ and mixture of pyroclastic and epiclastic (non-volcanic) rocks. These are categorized as tuffaceous sandstone, tuffaceous siltstone and tuffaceous shale. However, since $>80 \%$ area is of finer than $2 \mathrm{~mm}$, the ash flow/fall tuff must be the most appropriate term that should be used for this sequence. Genetically, most common effusive and rarely mild explosive eruption phenomenon can be explained from lava flow and pyroclastic fall and surge deposits in the field. Three major types of transportation mechanisms (mass-flow, traction, and suspension) are noted on the basis of textural features. Small sized lapilli are frequently seen as more or less uniformly embedded in ash/tuffaceous 

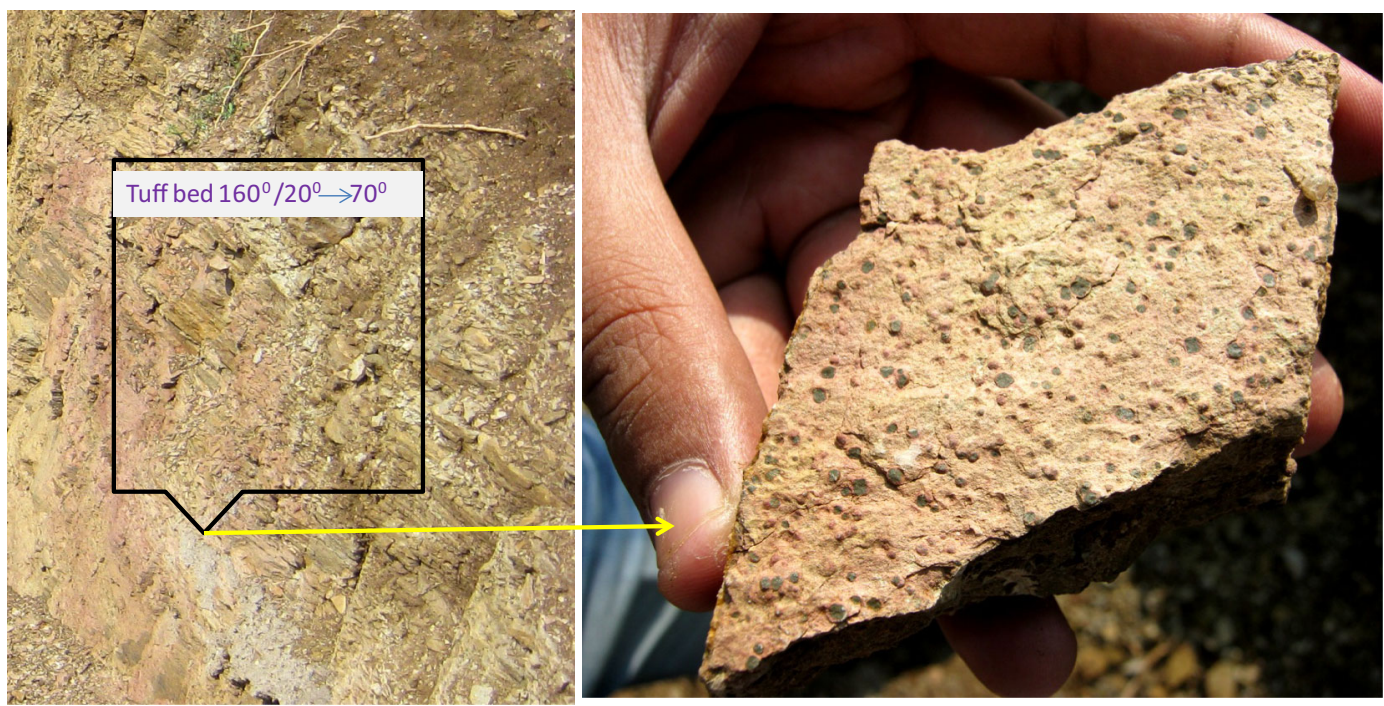

Figure 2. Tuffaceous bed with small circular embedded lapilli.
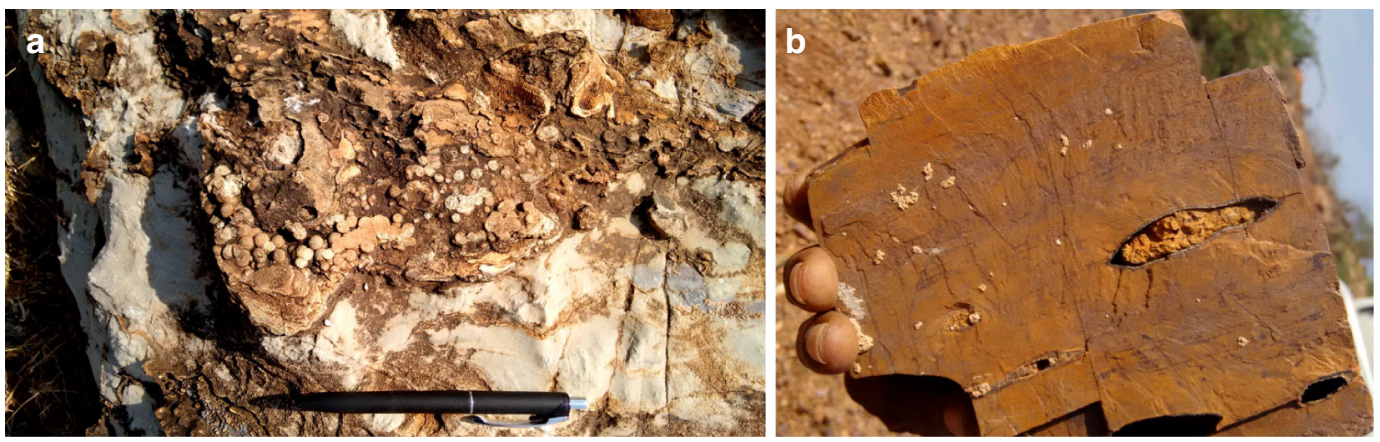

Figure 3. (a) Spherulites and (b) lithophysae in filled with secondary materials.

shale (figure 2). As far as basic characteristics of lavas and syn-volcanic intrusions are concerned, the coherent facies is characterised by porphyritic texture and aphanitic texture that consists of a mosaic of crystals too small to be seen without magnification. High temperature devitrification textures (figure 3) common in groundmass (e.g., spherulites, lithophysae and micro-poikilitic texture). These are vesicular to non-vesicular and internally massive to flow foliated. Light coloured porous pumice with a network of escaped gas bubble holes, frozen amidst fragile volcanic glass and minerals indicate explosive eruptions (figure 4). Pyroclastic deposits of the entire area are studied and based on different sections and across strike traverses, a composite representative litholog is prepared (figure 5). The litholog incorporated a bottom-to-top lithounit consists of flow, fall and surge deposits and associated volcano-sedimentary features as well. At places, pyroclastic fall deposits are better preserved (e.g., Sajjaladine, Lavanuru, and Tonduru area) compared to other places (e.g., Beduduru, Burzupalle, Mallella, Bondladinne, Thimmapuram, and Ahobilapuram) where flow and surges are prominent. Hence, after taking all such sections into consideration, the composite lithocolumn is made. The areas where fall deposits are better preserved exhibit a grain size decreasing towards top. Conceptually, grain size of fall deposit must be decreasing towards top vertically and laterally, the size should decrease away from source fissure vent. However, confirmed source vent position was not possible to demarcate because of probable tectonics that took place in this old Proterozoic terrain. Thickness of fall deposit decreases away from source and thus ash fall thickness is observed more surrounding the main flow and surge at places which show broadly NW-SE trend and probable fissure trend as well. Fall deposits have a better chance to cool, while suspended and they are not properly welded by their own heat after deposition. Therefore, they are prone 

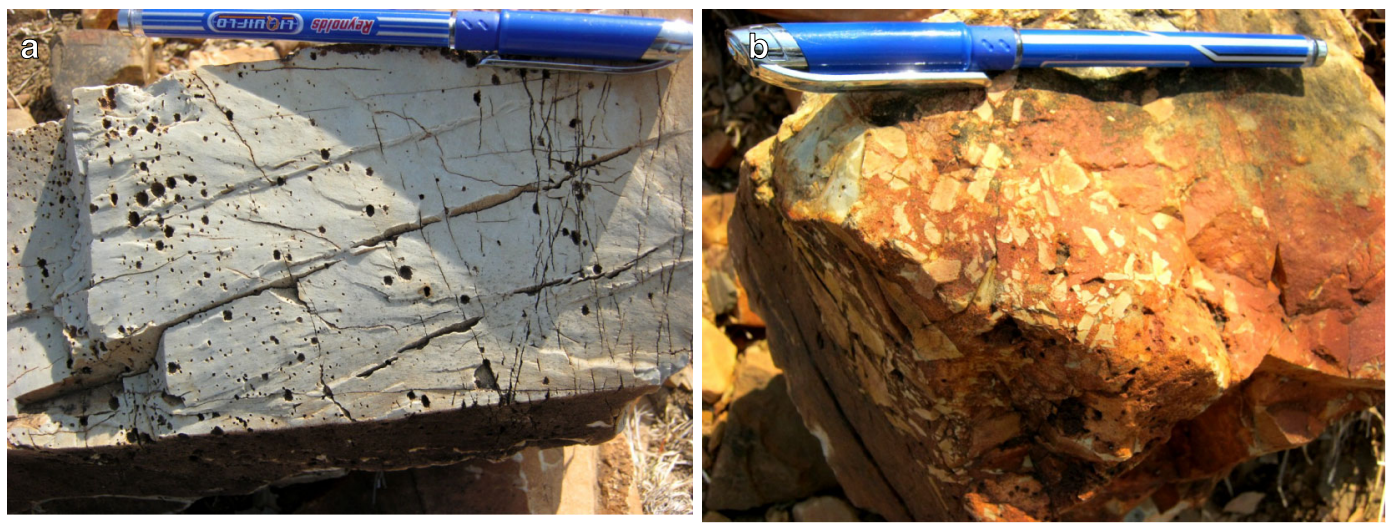

Figure 4. (a) Vesicular volcanic glass in the form of pumice in acid volcanics. (b) Brecciated volcanic glass with blocky, slabby and irregularly shaped clasts of lava as autobreccia.

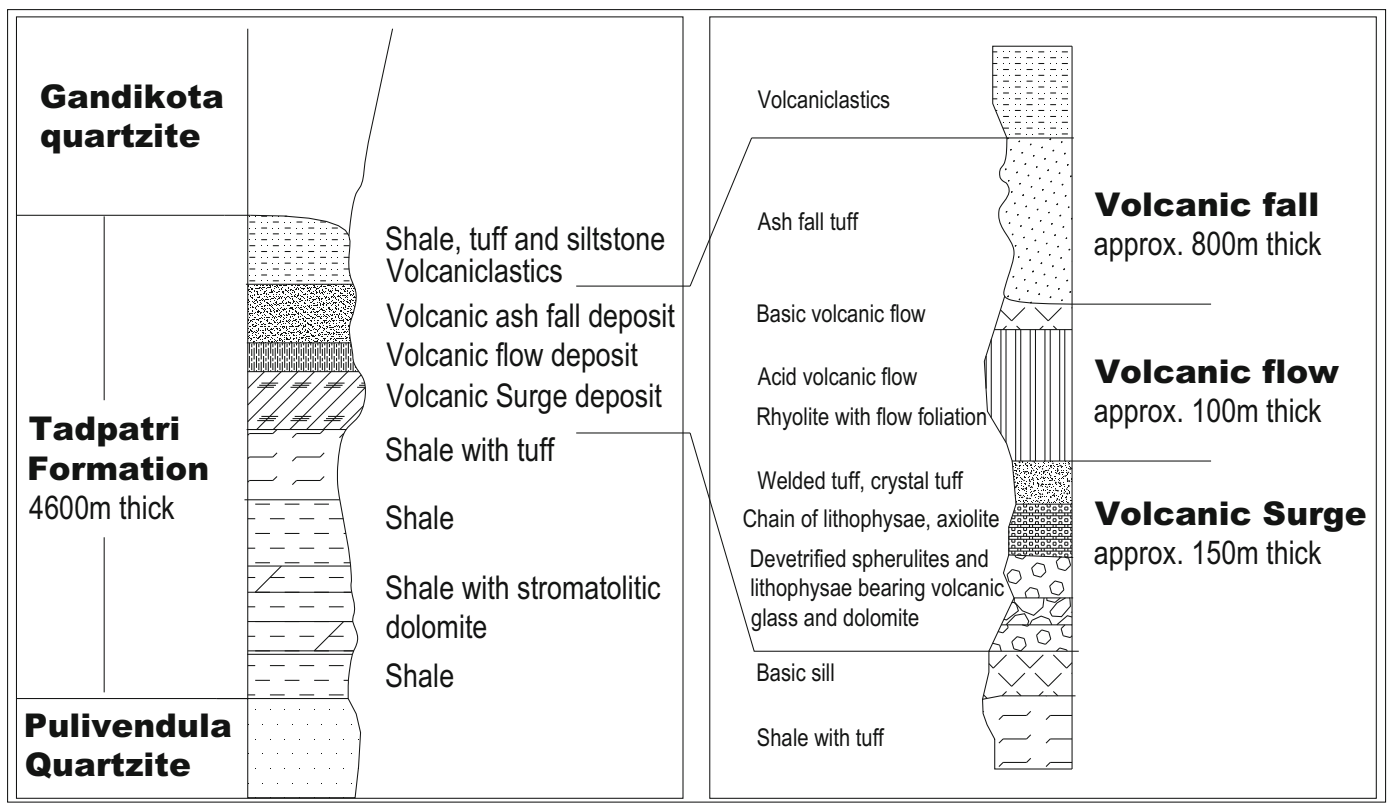

Figure 5. A representative composite log of the study area.

to be affected by subsequent surficial process like erosion to produce ultimately a shale and tuff mixture of volcano sedimentary sequence in down dip and hence, the top of the lithocolumn which indicates younger down slope volcaniclastic sequence are rich in shale. Unlike fall, the pyroclastic flow deposits are topography dependent and thus found to occur in the valley portion and they have lower viscosity than surge. Ash fall are distributed over larger area perhaps due to very small size and wind direction and velocity, but flow and surge deposits are relatively restricted and poorly sorted, less stratified. However, ash fall are welded at places probably due to high internal heat and compression related to weight of overlying mass in the lower part of depositional column. The lowermost portion of the litholog is composed of surge deposits which exhibit flow related depositional features like dunes, antidunes, ripples and cross-stratifications indicating a turbulent flow with less particle concentrations than in case of pyroclastic flow. Since pyroclastic surges have lower density but higher viscosity than flow, they are not as topographically constrained as normal flow (Nemeth and Martin 2007). The sequence of events that is represented by the entire area altogether is an initial lateral surge laying down the lowest deposit. This was followed by a pyroclastic flow event and after that entire surge and flow were covered by a blanket of slow settling ash fall to give a fining upward vertical sequence. Lateral variations are also apparent because the surge are restricted to the source fissure/vent area and flow are moderately restricted and tend to be deposited in lower topography; ash 
fall deposits are most frequently observed layer dispersed widely from source.

\subsection{Criteria for identification of volcaniclastics in field}

The identification of acid and basic volcanic rocks in Tadpatri Formation has already been recorded (Nagaraja Rao et al. 1987). This observation has been further substantiated by detailed field descriptions in this portion of the paper. The structures, which are described here, will provide evidences for the volcanic origin of the rocks which possess them and help field geologists to distinguish volcaniclastics from non-volcanic sediments and at that point to confirm about volcanic origin. Following conspicuous structures contain the history of the rock formation and merit to deserve a detailed description. This section presents a set of criteria for easy identification of volcanic origin of rock types.

- Differentiating tuff from shale was quite a tricky job in the field. To make the differentiation, basic criteria were fixed first by defining fine-grained clayey rocks with particles mostly less than $1 / 16 \mathrm{~mm}$ in diameter as tuffaceous shale with lapilli. The typical pyroclastic rocks generally contain more than $75 \%$ by volume of pyroclastic fragments, the remaining materials are generally of epiclastic, organic, chemical sedimentary or authigenic origin. Therefore, bedded tuff has been observed carefully to differentiate on the basis of an average pyroclast size of $1-0.5 \mathrm{~mm}$ embedded on fine clay size groundmass (figure 6 ). In the study area, most of the fine grained tuffaceous shale are confirmed and demarcated as volcano sedimentary sequence and differentiated from sedimentary non-volcanic shale on the basis of detail field observations.

- Spherulites, lithophysae and thundereggs have been found at places (e.g., Bedduduru, Thimmapuram, Lavanuru, Mallella, etc.). Spherulites are typically rounded or spherical aggregates of acicular crystals radiating from a single point. Lithophysae are generally radial or concentric
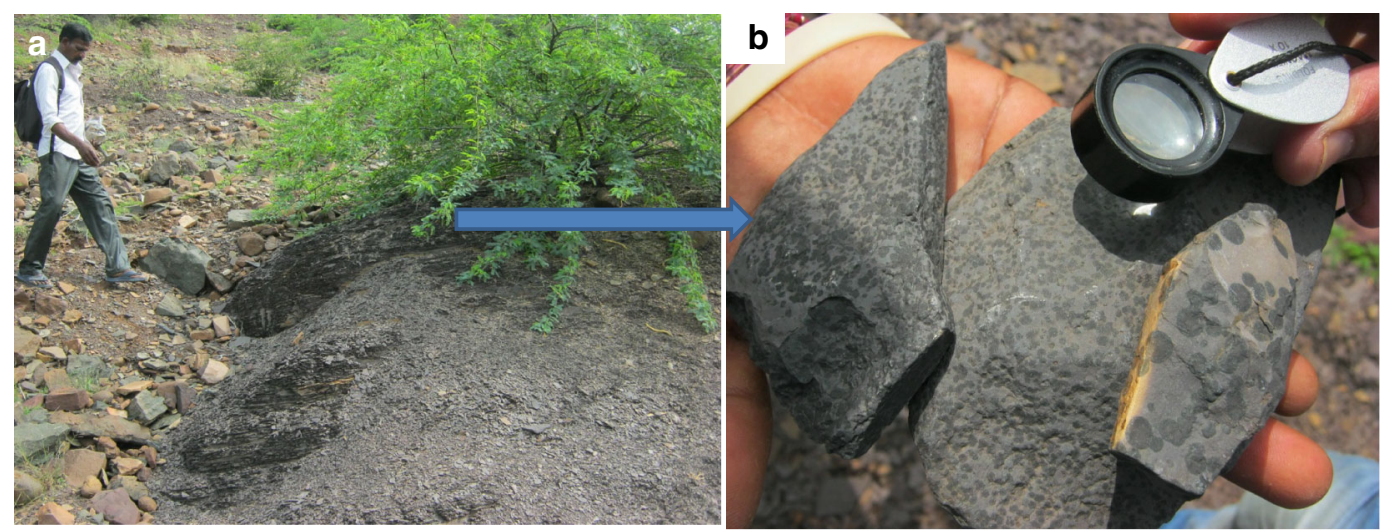

Figure 6. Bedded tuff with pyroclast size of $1-0.5 \mathrm{~mm}$ embedded on fine clay size groundmass.
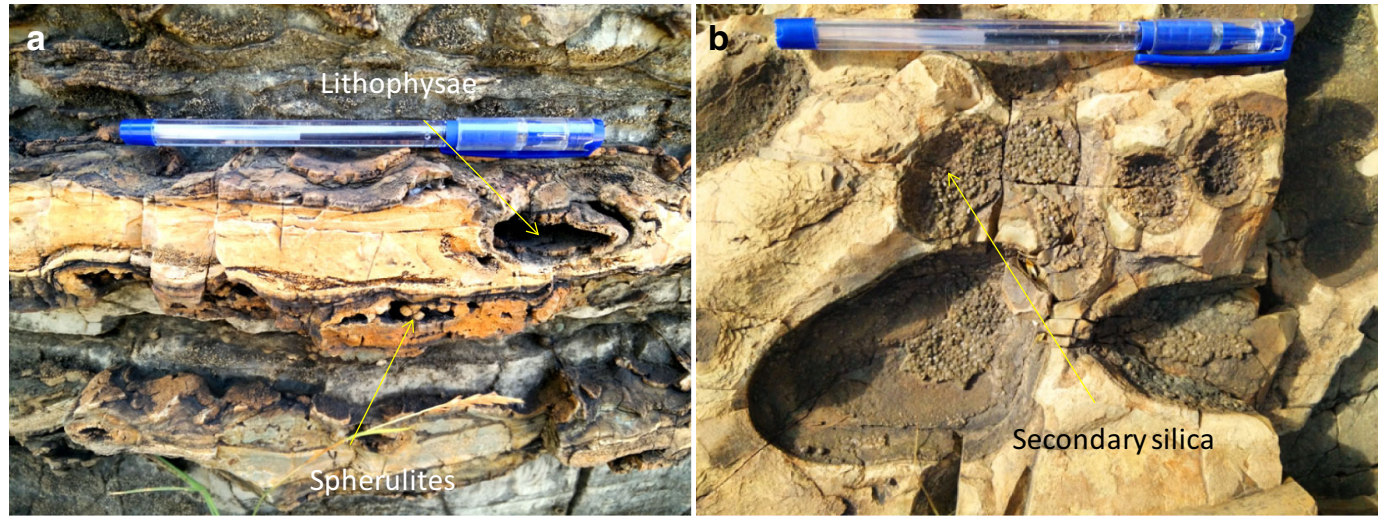

Figure 7. (a) Field outcrop photo of Lithophysae, Spherulites, glass. (b) Thunder eggs with infilled secondary silica. 


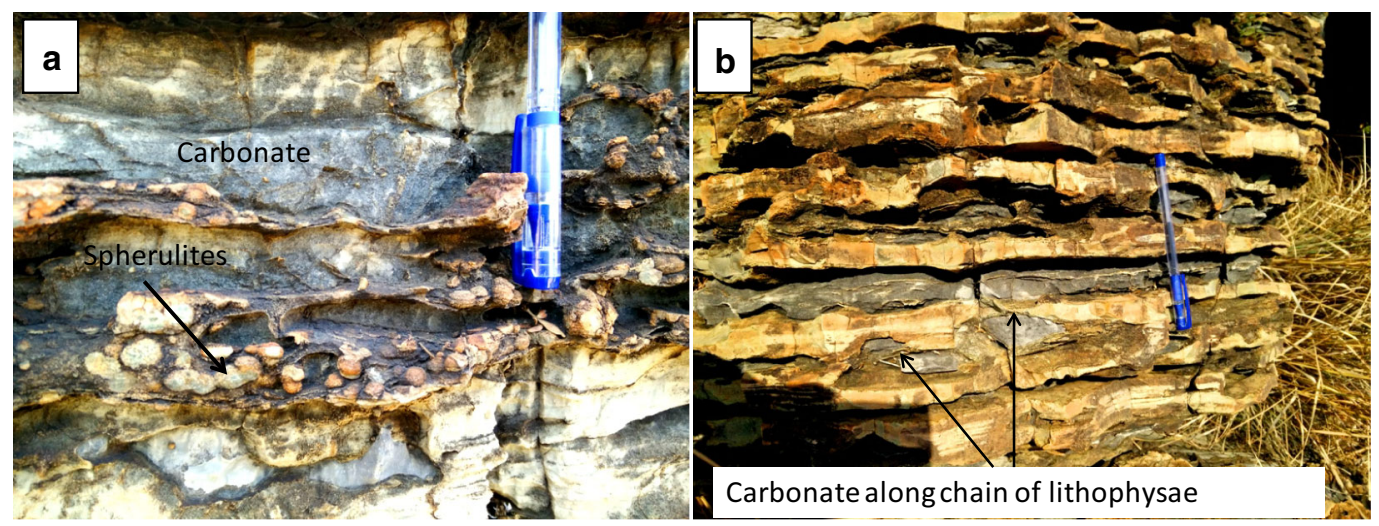

Figure 8. Chain of (a) Spherulites and (b) Lithophysae and later formed calcite shows white colour.

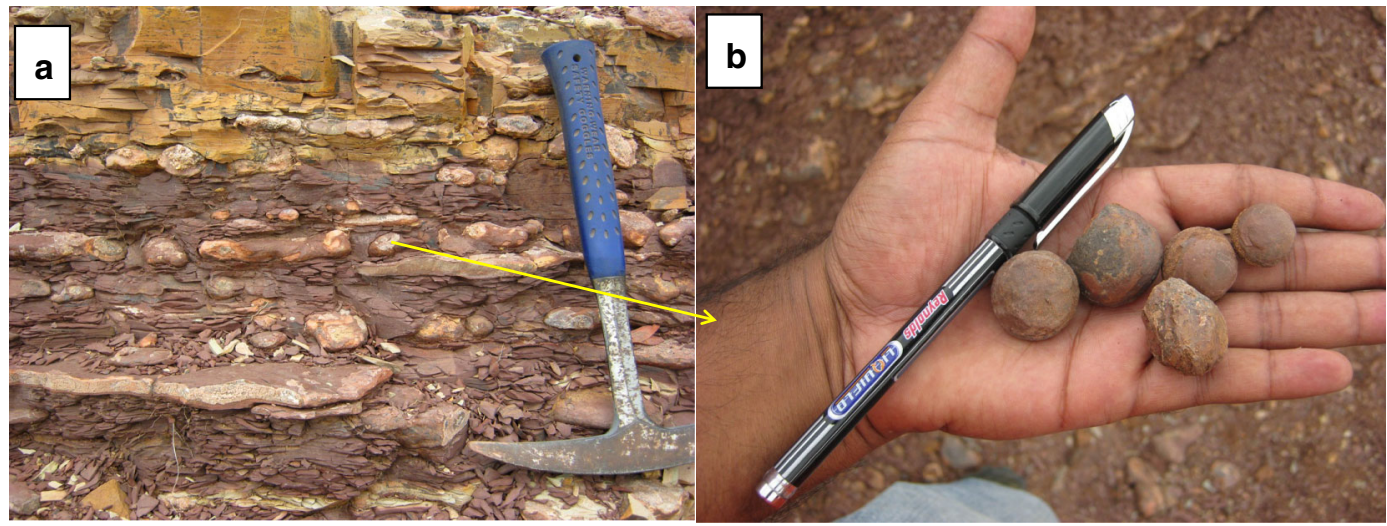

Figure 9. Spherulitic balls in (a) outcrop scale and (b) hand specimen scale.

cavities that is hollow, or partly to completely filled with later minerals and are associated with spherulites (figure 7a). Thundereggs are solid lithophysae lacking radial structure and filled with secondary silica (figure 7b). Spherulites, lithophysae and thundereggs are not found in comparatively silica-poor rocks. Several hypotheses have been proposed about the origin of lithophysae/thundereggs (Iddings 1887; Ross 1941; Wenyan and Xueyi 2013). However, there is no systematic model to explain the whole process. Spherulites shows diameters of $0.1-2.0 \mathrm{~cm}$ formed during devitrification. Isolated spherulites are generally spherical, but adjacent spherulites may impinge upon one another to produce long chains that are often aligned with flow foliation (figure 8). Tuff can store heat for long time, hence more or less completely recrystallized or silicified. In the center of a spherulite, sometimes there is a crystal (e.g., quartz or feldspar) or sometimes a cavity. When brought out in relief by weathering, these spherulites give to the rock a superficial resemblance to a conglomerate composed of rounded pebbles of uniform size and shape (figure 9). Presence of accretionary lapilli in the form of mud balls which result from a wet nucleus falling through a volcanic ash cloud is indicated by spherical aggregates of mud lumps at places (figure 10a). Another important feature noted in the field is called blister, characterised by swelling of the crust of a lava flow formed by the puffing-up of gas or vapour beneath the flow. Blisters are about $1-10 \mathrm{~cm}$ in diameter and hollow (figure 10b).

- The suspended rigid crystals, volatile-fluid bubbles, and distinctive mineral aggregates embedded in lava as flow foliation can serve as flow markers in association with other devitrification features which can give clue towards volcanogenic origin. The basic volcanics are very well indicating flow regime where feldspar laths rotate into a stable orientation that imparts foliation (igneous lamination) to the magmatic body (figure 11a). The phenocryst rich and phenocryst poor layers are originated due to the non-uniform planar flow as per the model proposed by Best (2003). Plagioclase laths are phenocryst in the basalt which result from slower cooling beneath 

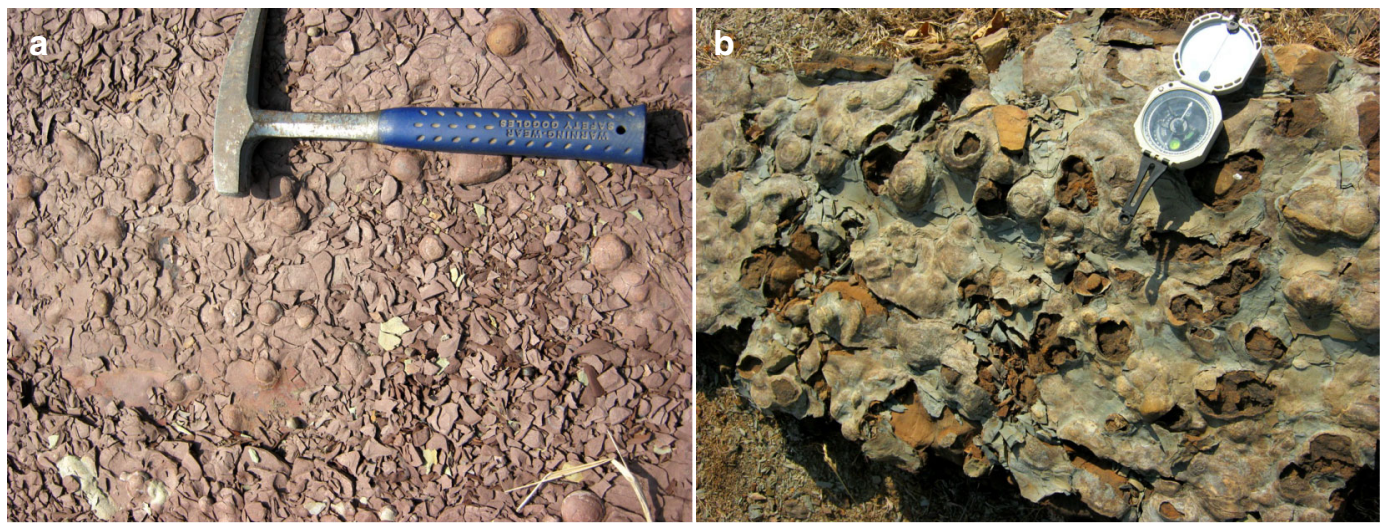

Figure 10. (a) The accretionary lapilli in the form of mud balls. (b) Blisters in lava flow.
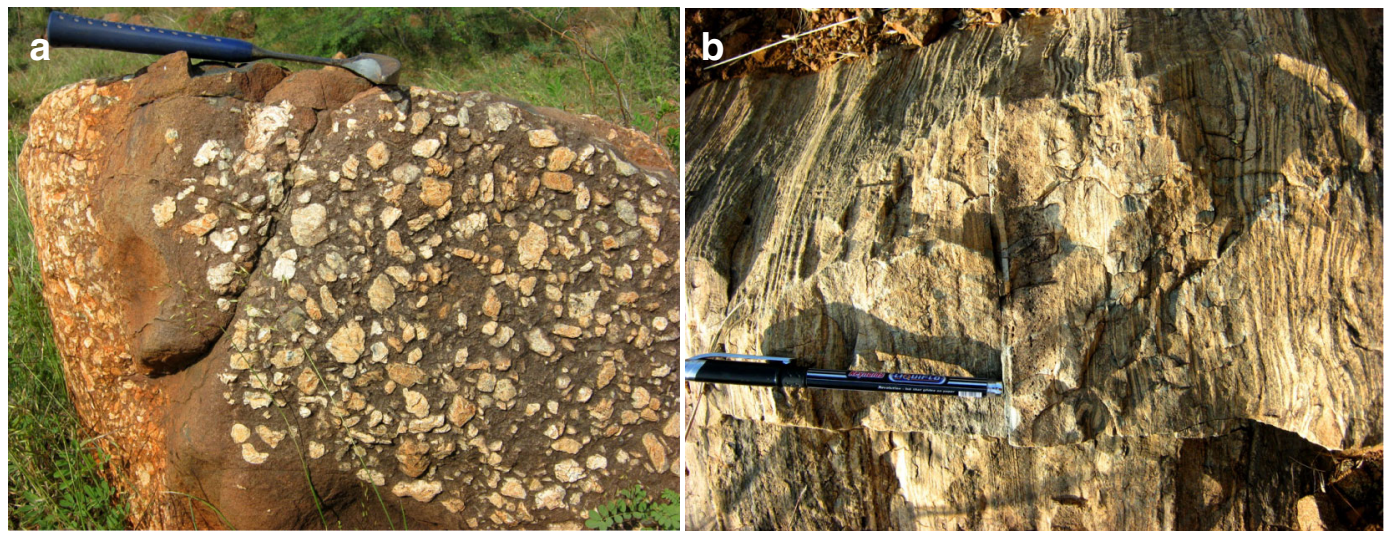

Figure 11. (a) Porphyry basalt layers as flow layering of alternate feldspar lath rich and lath free basic lava. (b) Flow foliation in acid volcanics.

the surface prior to eruption. Upon eruption, the remaining liquid crystallizes to fine tabular or equant crystals comprising the groundmass. The basic flows show ophitic, sub-ophitic and intergranular texture in outcrop scale also. The more silicic lava typically exhibit flow foliation (figure 11b), which consist of bands of different colours which could have been different batches of mingled magma or portion of same magma with different temperature, composition, content crystal, $\mathrm{H}_{2} \mathrm{O}$, etc. The layers were then sheared, stretched, and folded during flow.

- Vesicles are common in the area as highly vesicular volcanic glass in the form of pumice in acid volcanics (figure 4a). Variations in their size, shape and abundance in lavas reflect the interplay of several controls, including original magma volatile content and viscosity, rates of decompression and diffusion, coalescence and interference of adjacent vesicles, and deformation during flowage. As magma rises to shallow levels prior to an eruption it may become saturated in volatiles, as a result of decompression, and/or as a result of crystallization of anhydrous phases (Sparks 1978a, b; Burnham 1983).

- Occurrences of volcanic glass (figure 12) implying rapid quenching of silicate melts. Hand specimens of glassy volcanic rocks have distinctive conchoidal fracture surfaces and glassy luster. However, most of the glassy portions are devitrified because glass is metastable thermodynamically. At places glasses are found to be replaced by alteration minerals such as zeolites, phyllosilicates or palagonite. Presence of most frequently observed white calcite as replacement is noteworthy (figures 8, 12b).

- Contraction that accompanies cooling of hot volcanic deposits and high-level intrusions produces a variety of more or less regular joints (figure 13) like radial columnar joints, concentric joints, and tortoise shell joints. These are related to cooling and contraction and they strongly influence the shapes of clasts in associated autoclastic deposits. 


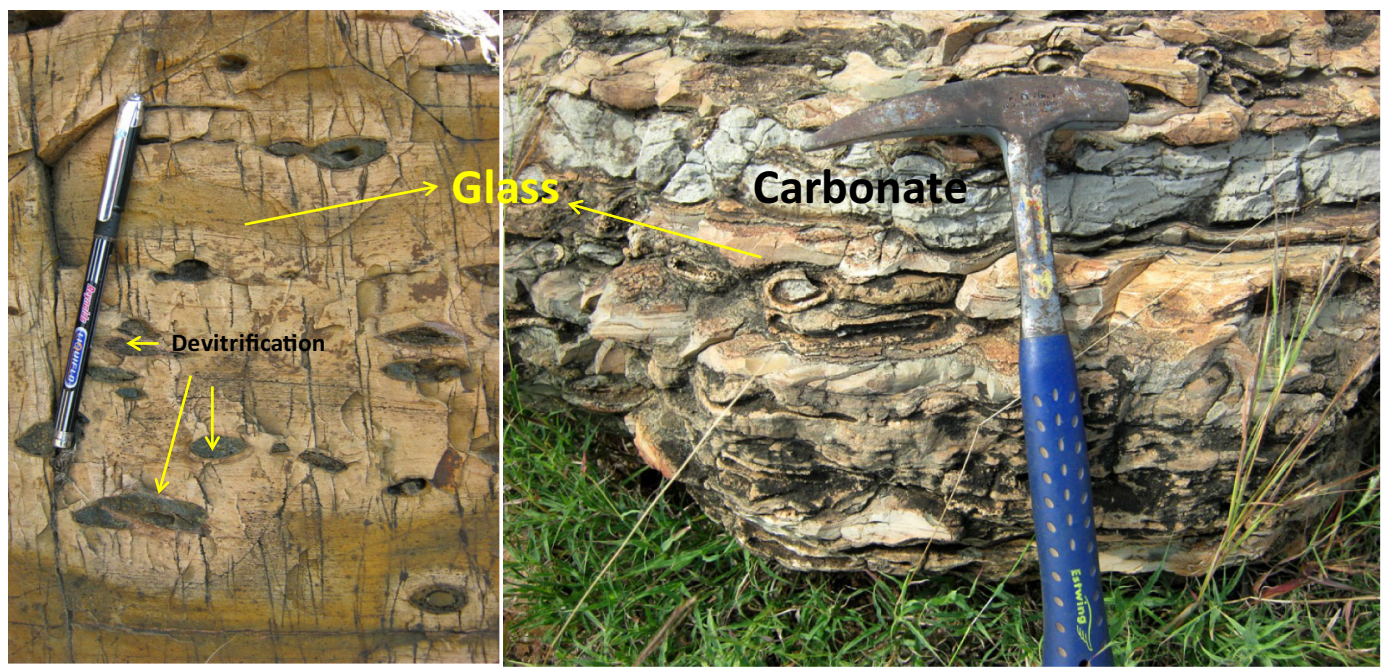

Figure 12. Volcanic glass with devitrification features of metastable glass.
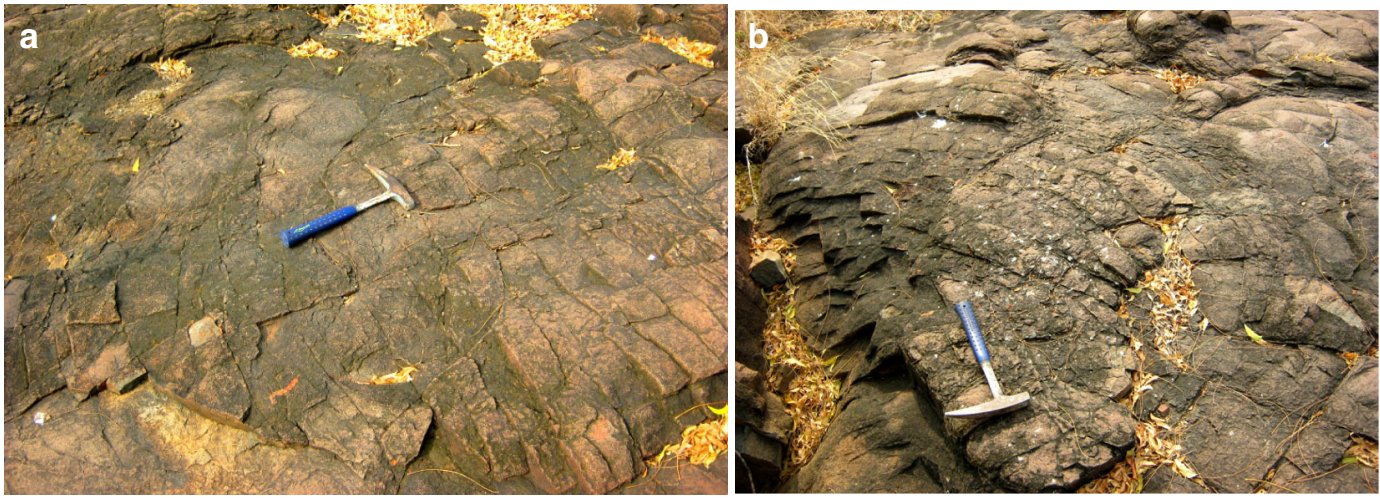

Figure 13. Cooling and contraction related joints in basic lava.

- Relatively less abundant autobreccia (figure 4b) is found as blocky, slabby and irregularly shaped clasts of lava which consists of flow banded and pumice clasts. The aggregates are monomict, clast supported, matrix-poor, poorly sorted, and grade into in situ jigsaw-fit lava breccia and fractured coherent lava.

- Peperite, a rock generated by mixing of coherent lava with unconsolidated wet sediment (Fisher 1960; Williams and McBirney 1979) characterized by a clastic texture in which either component may form the matrix, occurs at the contacts between intrusions and the sediments (figure 14) at places.

\section{Volcanic facies study}

The volcanic facies study focusses on the distinguishable volcanic units which have been mapped in outcrop scale only and thus, the study is specifically limited in the field. Structure, texture, internal organisation, geometry, etc., are identified in outcrop scale. At places, the identified volcanic lithofacies often revealed vertical and lateral variations and these are interpreted as changes in depositional behaviour of parental magma. Bimodal volcanic association is noteworthy in the field. In almost all the studied sections, basic volcanics are associated with acid volcanics with concordant relationships. Strike of both acid and basic flow beds is parallel and no cross-cutting relationships found. Such a bimodal occurrence is a characteristic of rift basin, thus supporting the tectonic setting of the Cuddapah basin. In order to distinguish volcanogenic sedimentary from resedimented volcaniclastic deposits, following evidences are taken into account:

- Evidence of significant transport or reworking prior to final redeposition. 

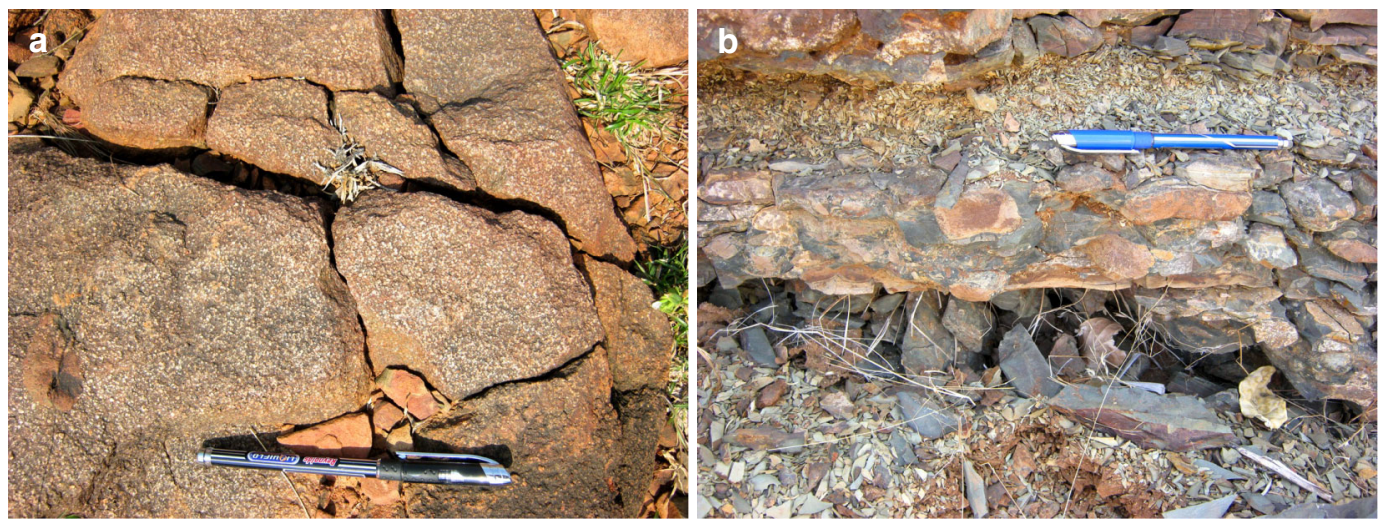

Figure 14. Field outcrop photo of peprites.

- Evidence that deposition of volcanics and associated clastics immediately after or even during eruption.

The entire study area comprises significant lithological, textural and compositional variations and for simplicity in understanding, the rocks are divided into a number of facies. The primary volcanic facies have been divided into mafic and silicic category. The silicic volcanic facies are studied in detail in this paper. The silicic volcanics are divided into volcaniclastic and coherent facies. The rock types are observed to occur regularly and contain distinctive features with a unique appearance that distinguishes them from other intervals or associations of rock types. We have assigned these rock types as different facies for identifying, describing and interpreting in a distinctive way. At a regional level four facies (surge, flow, fall and resedimented volcaniclastics) are demarcated to describe stratigraphic units of overall lithological character that distinguishes them from other units. At a more local scale, facies have been defined at the scale of an outcrop by an interval of one or several beds which is basically uniform. It is true that the degree of detail used in subdividing the stratigraphic succession into facies is controlled by the aims of the study, the information available and the level of understanding. Therefore, present study is restricted in regional scale. Local outcrop scale facies also have been described to understand that although associated facies may be different in outcrop scale they may still be genetically related as parts of the same depositional or eruptive event regionally. In the outcrop scale, individual facies within the sequences are highly variable both vertically and laterally and correlation of facies within a particular sequence over distances as short as $0.5 \mathrm{~km}$ is not even possible.
The felsic volcaniclastic rocks of the area display a wide range of textures and structures, but all are characterized mineralogically by abundant quartz, feldspar and glass along with calcite which have formed later. The normative mineralogy is dacitic to rhyolitic. The principal components of these rocks are a matrix, crystal clasts or phenocrysts, and lithic clasts, all of which occur in highly variable proportions in different units. The matrix is dominantly fine- to medium-grained, made up of glass, feldspar and quartz. Present study has followed the grain-size terms for primary volcaniclastic rocks after White and Houghton (2006). The volcaniclastic grain-size nomenclature is followed similar to clastic sedimentology. When clay $(<1 / 16 \mathrm{~mm})$ is lithified, it is called shale and sand ( 2 to $1 / 16 \mathrm{~mm}$ ) as sandstone in clastic sedimentology. Similarly, in this volcaniclastic study, the grain size with 2 to $1 / 16 \mathrm{~mm}$ are called ash, which is termed as tuff for the lithified consolidated form. The $<1 / 16 \mathrm{~mm}$ grains are marked as extremely fine ash. The $2-64 \mathrm{~mm}$ sizes are called lapilli which forms lapilli-tuff when lithified. The $>64 \mathrm{~mm}$ size grains are termed as block (if angular) or bomb (if rounded) which are termed as breccia in lithified form. Since, the field outcrops exhibit the lithified form rather than unconsolidated grains in the succession, the terms tuff, lapilli-tuff and tuff-breccia is used for ash, lapilli and block/bomb, respectively. Unlike sedimentary facies, short distance facies variations are observed at several places where the recognition of proximal to distal facies variations as well as the establishment of a correct stratigraphy have been done after preparation of standard litholog (figure 5). The detail descriptions of surge, flow and fall is presented in petrography section (figures 15-18) along with hand specimen photo. Further, geochemical studies become useful 

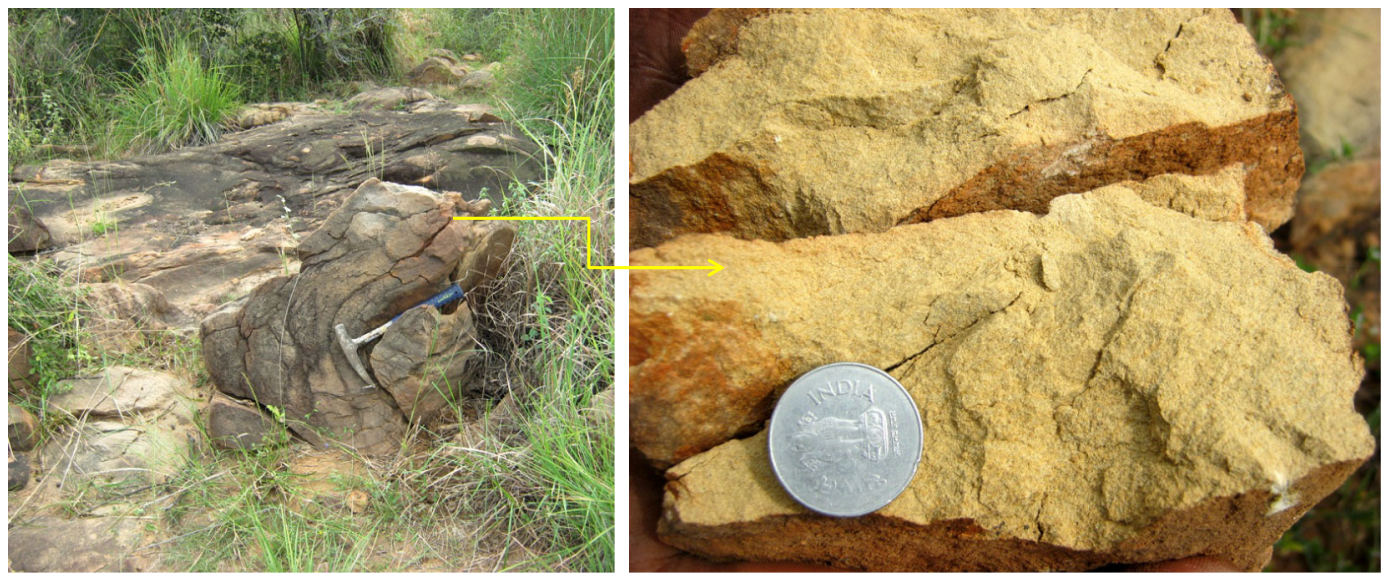

Figure 15. Volcanic surge facies in outcrop and hand specimen scale.
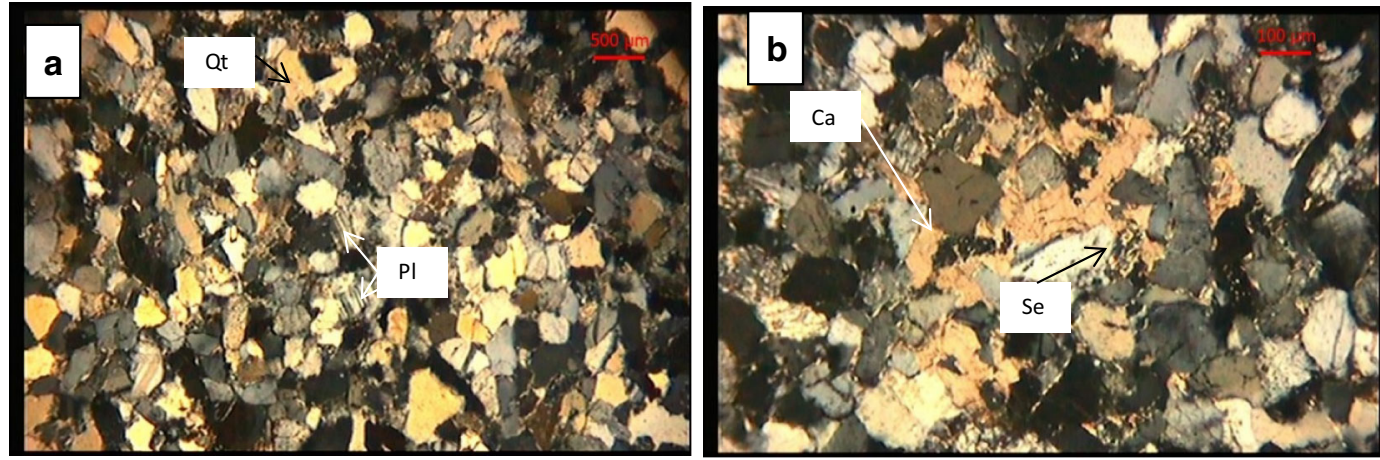

Figure 16. (a) General texture of surge of rhyolitic composition; Subhedral grains of perthite, microcline, plagioclase and quartz show hypidiomorphic granular texture. $\mathrm{Qt}=\mathrm{Quartz}, \mathrm{Pl}=$ Plagioclase. (b) Calcite (Ca) and sericite (Se) in the interstitial spaces TL, $2 \mathrm{~N}$.

to demonstrate facies changes and to identify facies relationships.

Plate 1 shows the outcrop scale facies descriptions near Beduduru area where relatively good outcrop section with most of the representative facies are observed as follows:

- Facies 1: Basic flow beds with parallel strike and dip with associated sequence. Medium- to fine-grained mafic rock in which ophitic and subophitic texture can be seen under hand lens.

- Facies 2: Very fine surge type mixture of ash and lapille. Moderately hard welded rock with spotty appearance.

- Facies 3: Almost similar to facies 2, but colour difference seen possibly due to compositional contrast.

- Facies 4: Acid volcanic flow facies marked as ' $A$ ' in plate 1 . Vesicles are noteworthy and minerals are too fine to identify in field. This facies can be subdivided into few sub-facies based on minor differences in colour, outlook and grain sizes. In the present context further detailed study is not done.

- Facies 5: Ash fall tuff beds show small droplets of ash possibly in hot condition and subsequent cooling caused welding.

- Facies 6: Shale-siltstone beds with primary sedimentary features like cross bedding, ripples, etc.

In these old volcanic successions, the source volcano might have been eroded or displaced by tectonic processes into far position, hindering the identification of proximal to distal facies relationships. However, the most important fact in studying such old volcanic succession is that the volcanic rocks accumulated and preserved in basinal setting. Basin fills perhaps can be intercalated with distal facies portions of primary to secondary volcaniclastic successions, and only inference of the texture, extension, and geometry of the proximal volcanic deposits is made. For the field geologists, to proceed into appropriate descriptive 


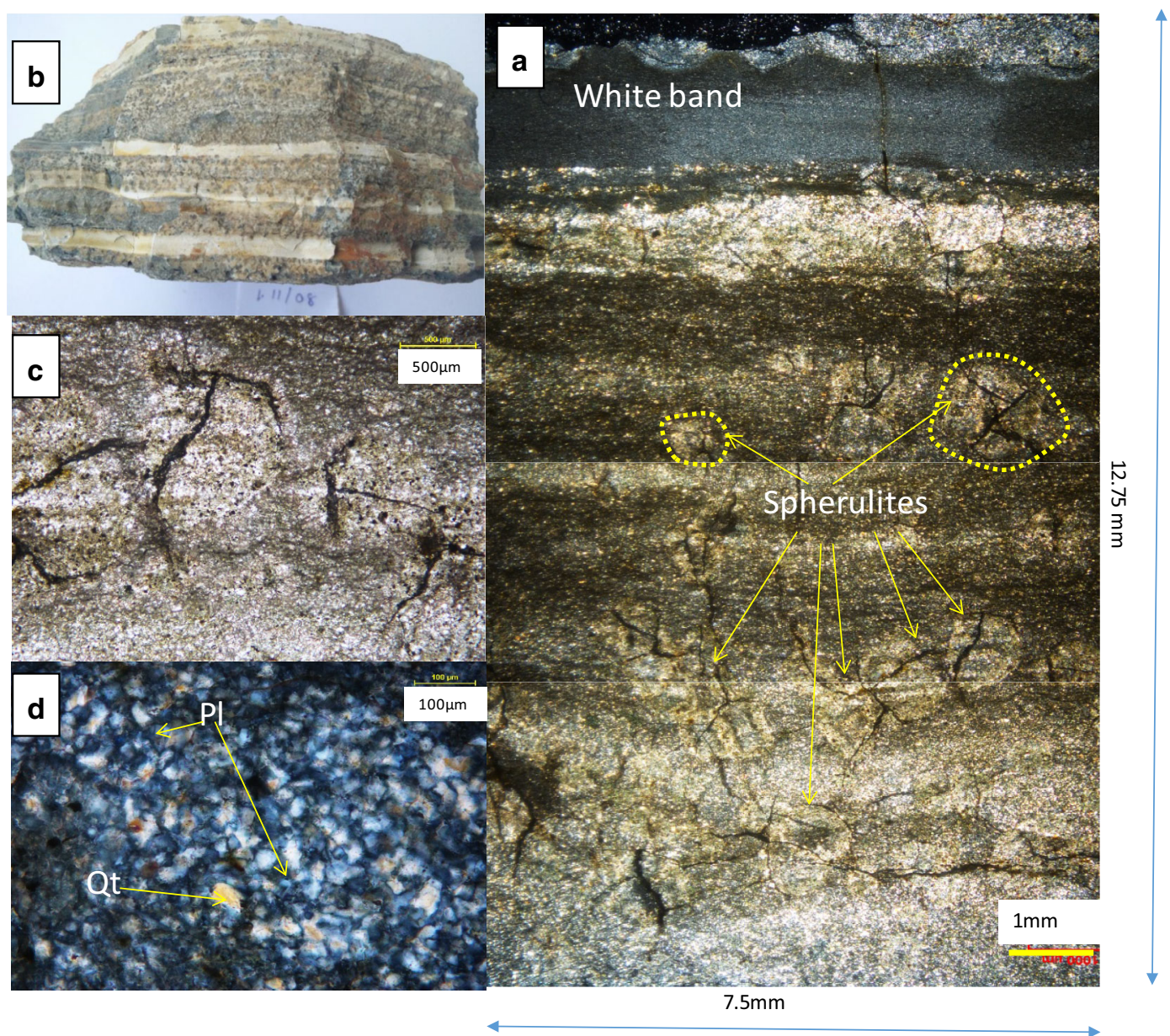

Figure 17. (a) The overall texture of the flow banded rhyolite with spherulites under microscope; transmitted light (TL), cross nicols (XN), 2X. Minute observation can show sub-circular spots of spherulites related to devitrification. (b) Hand specimen of the banded rhyolite. (c) Spherulites in banded rhyolite and anatase is present along the fractures TL, XN, 20X. (d) Texture of groundmass with fine anhedral granular quartz and feldspar in spherulitic banded rhyolite TL, XN, 20X.

terminology followed by genetic interpretation, it is important to make a decision whether the texture are of volcaniclastic or coherent category. Therefore, more information are collected from mapping and thin-section studies and after understanding, the features initial decision have been reviewed and evaluated.

\section{Petrography}

The volcanic surge deposits have a resemblance with fine arenites without bedding planes and quartz grains can come out easily from hand specimen due to absence of cementing materials (figure 15). Under the microscope fresh subhedral to euhedral quartz with insignificant cementing material is characteristics of this rock (figure 16). Most of the rocks have undergone massive calcification later, which has obliterated the texture and the minerals are replaced by anhedral calcite having an average size of $40-80 \mu \mathrm{m}$.

The volcanic flows are banded with alternate glassy and devitrified layers (figure 17). White coloured altered glass layers are consisting of some fine grained argillaceous minerals. The devitrified portions are made up of dominantly spherulites composed of chlorite with some quartz. Chlorite is formed due to alteration of feldspar. Development of feldspar spherulites due to nucleation inhibiting crystal growth is also observed. Spherulites up to $2.5 \mathrm{~mm}$ in size also occur in some parts of the specimen and these are embedded on anhedral granular quartz and feldspar rich mass. Anatase is observed along some fractures. As far as the ash fall is concerned, fine-grained, grey to white banded rock with sub-spherical mineral grains is noteworthy (figure 18). The rock is composed of 


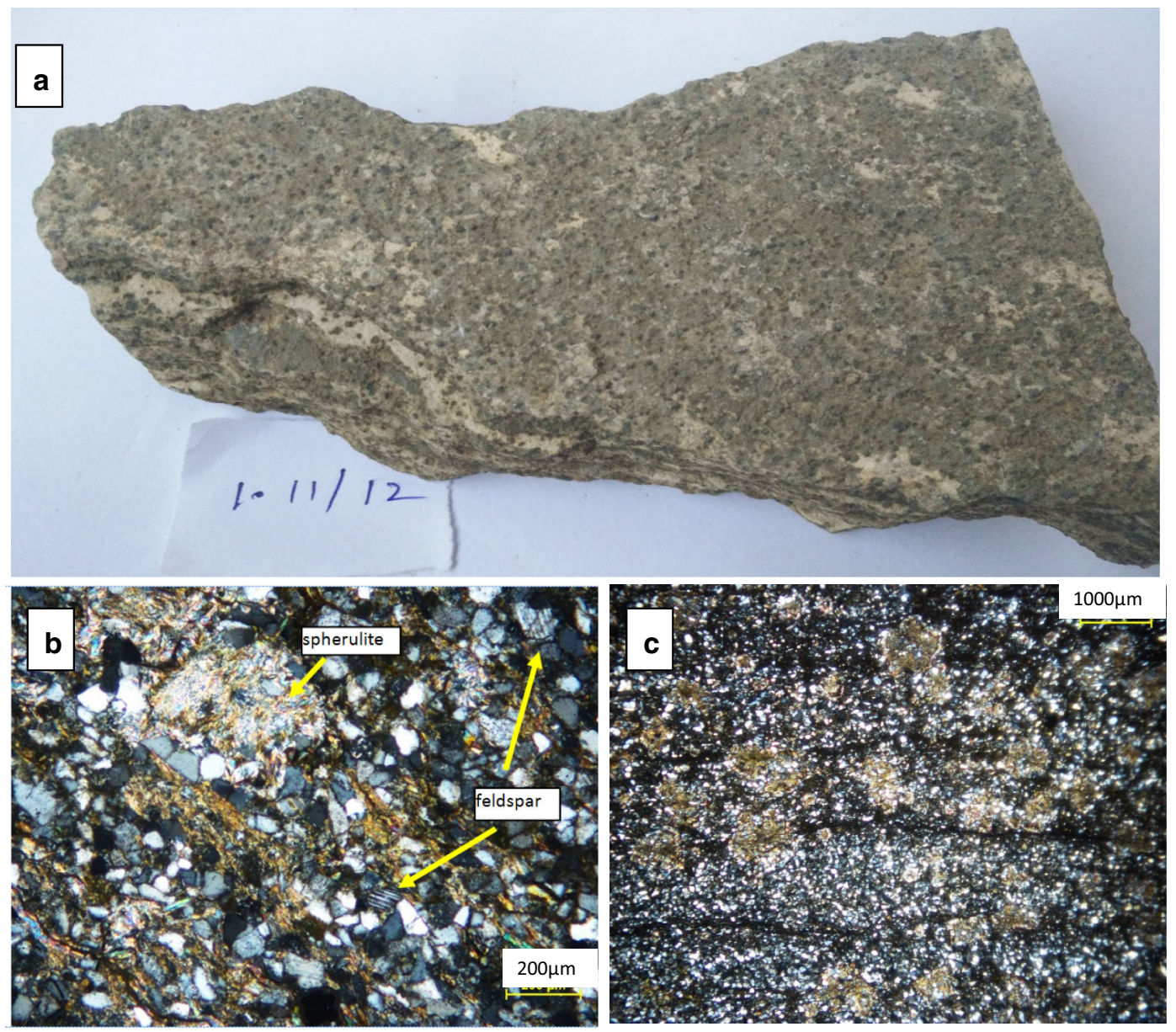

Figure 18. (a) Hand specimen of ash fall tuff. (b) Texture of Spherulitic banded rhyolitic tuff TL, XN, 2X. (c) Spherulite and bandings TL, XN, 10X.

fine sized quartz, sericite and chlorite. All the grains are aligned along the banding. It is a high temperature devitrified rhyolitic ash fall which has undergone intense alteration. The feldspars are altered to sericite and chlorite. Spherulite, primarily of feldspar is replaced by chlorite and sericite.

Thin section is also prepared across the lithophysae and spherulites in calcified tuff in which boundary of the lithophysae shows fine-grained and euhedral zoned plagioclase (figure 19a-d). Occurrences of cryptocrystalline quartz due to devitrification of glass is also evident. The central part of the euhedral zoned phenocryst of plagioclase is altered to clayey/chloritic minerals (figure 19f). At places the feldspars are found to be altered in to clayey (chloritic) minerals. Figure 19(e) represents ideal fine radiating spherulites which often show borders of devitrified silica (figure 19g). Presence of euhedral zircons $\sim 0.05 \mathrm{~mm}$ (figure $19 \mathrm{~h}$ ) is frequent. Sometimes lapilli of chlorite, quartz and feldspar are observed. Lithic tuff having a matrix of vitroclastic nature with devitrified glass shards and also vitreous tuffs with felsitic groundmass with chloritised glass shards and chlorite lapilli are observed. There are variations in the degree of devitrification between groundmass and lapilli. Zircon, tourmaline, biotite, apatite and perthite are present in minor to trace amount. Quartz, feldspar and glass make up $70-98 \%$ of the matrix.

The basic volcanics consist of olivine, augite and plagioclase feldspar with sub-ophitic, porphyritic textures. Alteration is markedly found in olivine which is serpentinised, augite alters to amphibole and plagioclase has suffered intense sericitization. Euhedral skeletal ilmenite, anhedral chalcopyrite and pyrite are the iron sulphides present in these basic (figure 20) rocks.

\section{Geochemistry}

Thirteen samples representing different stratigraphic levels were analysed for major and selective trace elements (tables 1 and 2) at X-ray 


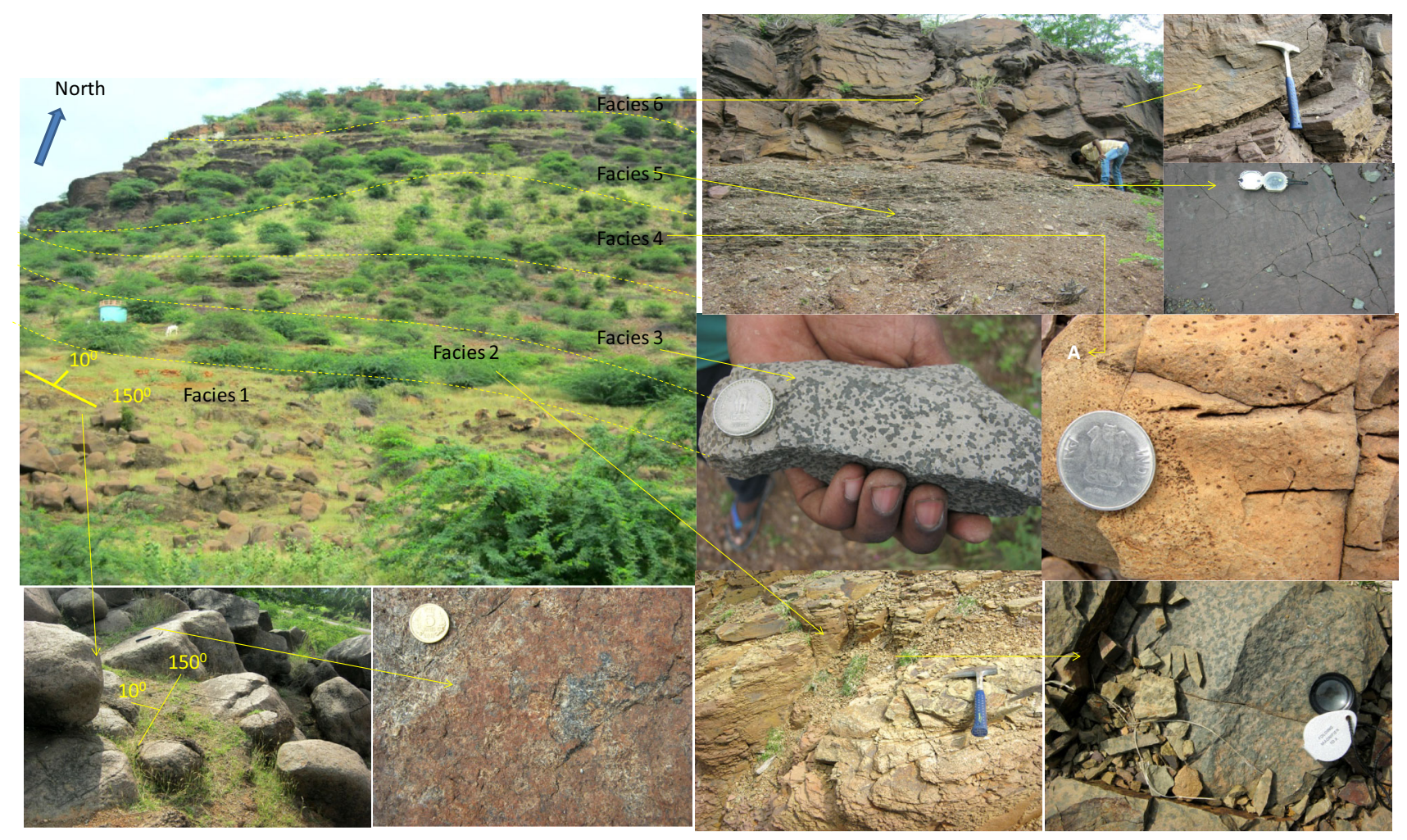

Plate 1. Summarised volcanic facies with outcrop photographs near Beduduru area.

Fluorescence Spectrometry (XRF) Laboratory, Atomic Minerals Directorate for Exploration and Research, Hyderabad. The compositional variation among the volcaniclastic rocks is restricted within limit and they belong to mainly tholleitic series of magma. However, compared to mafic volcanics, acid volcanics and tuffaceous rocks show discrepancies due to devitrification with associated alteration, calcification and clastic admixing. AFM plot (after Irvine and Barager 1971) gives both tholleiite and calcalkaline series as the parent magma composition for acidic rocks in contrary to mafic counterparts (figure 21a). Carbonatization in two samples has affected the original composition. Hence, few samples are falling in calcalkaline field due to devitrification and associated alteration. Molar $\mathrm{Al}_{2} \mathrm{O}_{3}-\mathrm{K}_{2} \mathrm{O}-\mathrm{Na}_{2} \mathrm{O}$ plot has shown mainly peraluminous to metaluminous type of magma for both basic and acidic rocks (figure 21b). Flow beds of mafic and felsic rocks are occurring together in field (figure 21c, d) and this bimodal association is characteristic of rift setting and tholleitic magmatism. The calcified samples are chemically altered, but Chemical Index of Alteration $\{\mathrm{CIA}=$ $\left.\mathrm{Al}_{2} \mathrm{O}_{3} /\left(\mathrm{Al}_{2} \mathrm{O}_{3}+\mathrm{CaO}+\mathrm{K}_{2} \mathrm{O}+\mathrm{Na}_{2} \mathrm{O}\right) \times 100\right\}$ value (Nesbitt and Young 1982; McLennan et al. 1993) cannot be determined because $\mathrm{CaO}$ should be derived from silicate minerals only. CIA values of tuff are relatively higher due to removal of labile cations $\left(\mathrm{Ca}^{2+}, \mathrm{Na}^{+}, \mathrm{K}^{+}\right)$relative to stable residual constituent $\left(\mathrm{Al}^{3+}, \mathrm{Ti}^{4+}\right)$. Calcified samples have shown Loss On Ignition (LOI) as high as $35 \%$ in elemental or oxide analysis. The volatile materials lost consist dominantly of carbon dioxide derived from carbonates and minor hydrates and labile hydroxy-compounds. Felsic Index $\{\mathrm{FI}=$ $\left.\left(\mathrm{Na}_{2} \mathrm{O}+\mathrm{K}_{2} \mathrm{O}\right) \times 100 /\left(\mathrm{CaO}+\mathrm{Na}_{2} \mathrm{O}+\mathrm{K}_{2} \mathrm{O}\right)\right\}$ gives an idea about the increase in $\mathrm{K}_{2} \mathrm{O}$ and $\mathrm{Na}_{2} \mathrm{O}$ at the expense of $\mathrm{CaO}$ during fractionation (Simpson 1954). However, some of the samples have very less content of $\mathrm{MgO}, \mathrm{MnO}, \mathrm{K}_{2} \mathrm{O}$ and $\mathrm{Na}_{2} \mathrm{O}$ below the detectable limit and thus, alteration studies have not been carried out for those samples. Ishikawa Alteration Index $\left\{\mathrm{IAI}=\left(\mathrm{K}_{2} \mathrm{O}+\right.\right.$ $\left.\mathrm{MgO}) \times 100 /\left(\mathrm{K}_{2} \mathrm{O}+\mathrm{MgO}+\mathrm{Na}_{2} \mathrm{O}+\mathrm{CaO}\right)\right\}$ of the samples is a measure of intensity of sericite and chlorite alteration (Ishikawa et al. 1976) and useful in plagioclase destructive hydrothermal alteration systems (Gifkins et al. 2005). At places, tuffs are affected by sericitic alteration and hence provide higher IAI value. High value of $\mathrm{Ba}, \mathrm{Zr}$ for acid volcanic and tuff samples support field observations and petrography. In the $\mathrm{Nb} / \mathrm{Y}$ vs. $\mathrm{Zr} / \mathrm{TiO}_{2}$ diagram of Winchester and Floyd (1977), 

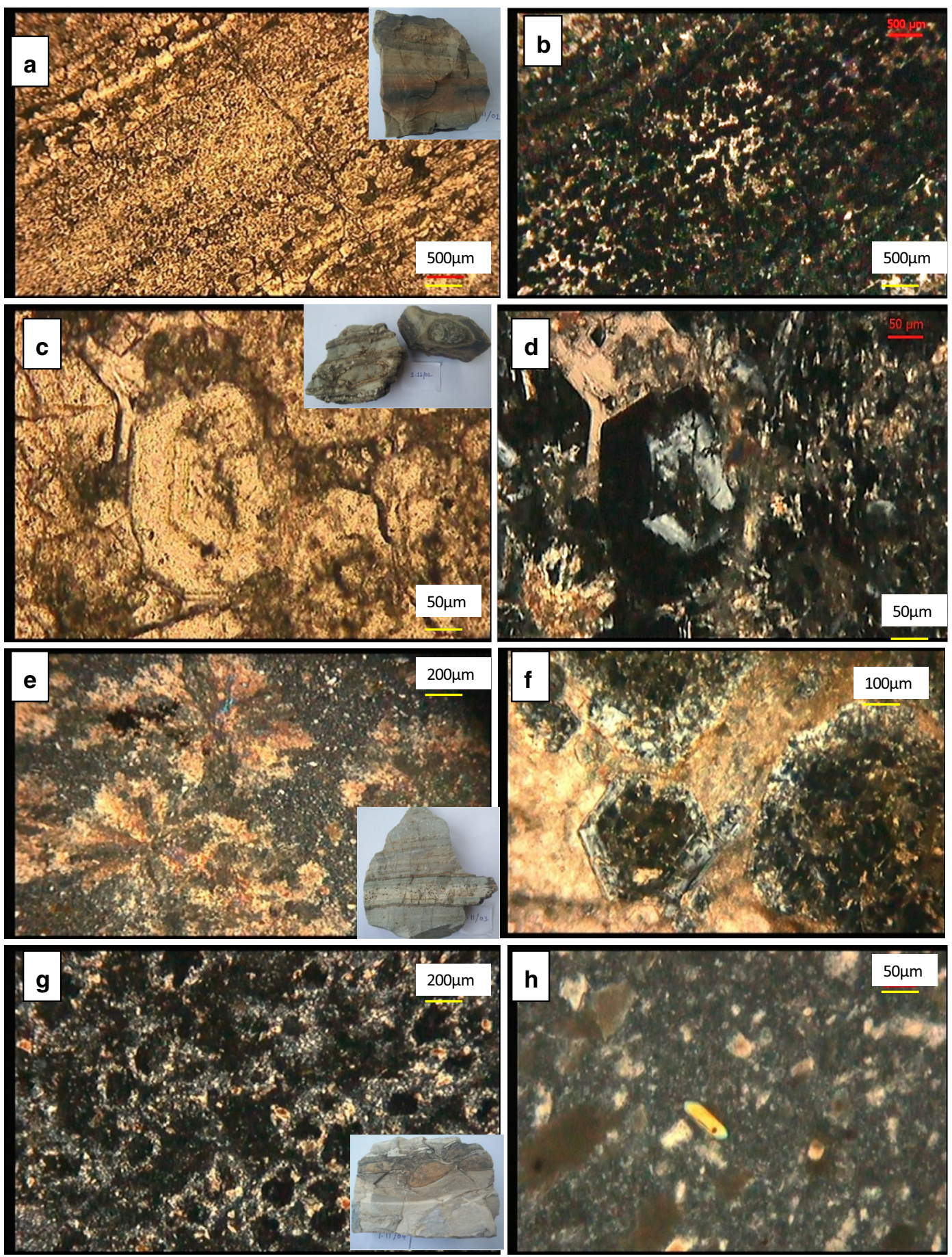

Figure 19. (a) The rim of spherulite in calcified spherulitic tuff TL, 1N; (b) The rim of spherulite in calcified spherulitic tuff TL, XN; (c) Phenocrysts of euhedral zoned plagioclase TL, 1N; (d) Euhedral zoned plagioclase phenocrysts under cross nicol, TL, XN; (e) Spherulites of cristobalite TL, XN; (f) Phenocryst of plagioclase alters to clay minerals in the center TL, XN; (g) Spherulite with silica at the borders TL, XN; (h) Zircon in spherulitic rhyolite TL, XN. All the insets are of respective sample in hand specimen scale.

majority of the acid volcanic and tuff samples fall in rhyodacite and dacite field and basic is in basalt field (figure 22a). At places considerable variation occurs due to incorporation of non-volcanogenic sediments as well as intense alteration. High degree of negative correlation $(-0.92)$ between $\mathrm{SiO}_{2}$ and $\mathrm{CaO}$ (table 3) points to carbonatization (figure $22 \mathrm{~b}$ ) promoted by fluids characterized by high partial pressures of carbon dioxide $\left(\mathrm{PCO}_{2}\right)$, low salinity and neutral-alkaline $\mathrm{pH}$. 

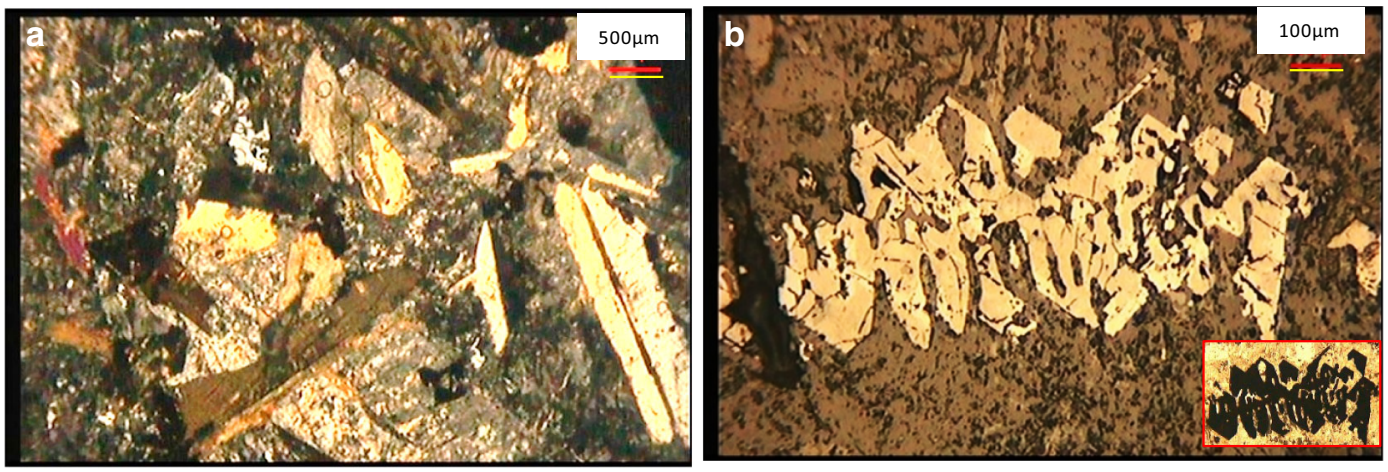

Figure 20. (a) Texture of altered dolerite TL, XN. Augite alters to amphibole and plagioclase have suffered intense sericitization; hence subophitic texture got slightly blurred. (b) Skeletal ilmenite reflected light (RL), 1N, in inset same in TL, $1 \mathrm{~N}$.

Table 1. (a) Major element oxides of 13 selective samples of the study area and alteration indices. (b) Trace element data of 13 selective samples of the study area.

\begin{tabular}{llcrrrrrrrrrrrr}
\hline Sl.no. & \multicolumn{1}{c}{ Rock } & $\mathrm{SiO}_{2}$ & $\mathrm{TiO}_{2}$ & $\mathrm{Al}_{2} \mathrm{O}_{3}$ & $\mathrm{Fe}_{2} \mathrm{O}_{3}^{\mathrm{t}}$ & $\mathrm{MnO}$ & $\mathrm{MgO}$ & $\mathrm{CaO}$ & $\mathrm{Na}_{2} \mathrm{O}$ & $\mathrm{K}_{2} \mathrm{O}$ & $\mathrm{P}_{2} \mathrm{O}_{5}$ & $\mathrm{CIA}$ & $\mathrm{FI}$ & $\mathrm{IAI}$ \\
\hline (a) & & & & & & & & & & & & & & \\
1 & Tuff & 58.40 & 0.25 & 10.48 & 7.10 & 0.32 & 1.12 & 8.65 & 2.79 & 1.39 & .02 & 44.96 & 32.58 & 17.99 \\
2 & Tuff & 60.82 & 0.65 & 18.15 & 10.27 & $<0.01$ & 5.23 & 0.97 & 1.32 & 2.25 & 0.06 & 79.99 & 78.63 & 76.56 \\
3 & Acid volcanic & 57.08 & 0.18 & 9.05 & 0.76 & 0.78 & 4.68 & 17.41 & 5.71 & $<0.01$ & 0.04 & $\mathrm{ND}$ & $\mathrm{ND}$ & $\mathrm{ND}$ \\
4 & Calcified spherulite & 15.28 & 0.17 & 2.58 & 1.35 & 0.09 & 1.15 & 45.56 & 0.08 & 0.04 & 0.16 & $\mathrm{NA}$ & $\mathrm{NA}$ & $\mathrm{NA}$ \\
5 & Basic volcanic & 49.85 & 1.74 & 12.81 & 14.85 & 0.20 & 4.83 & 9.54 & 2.47 & 1.09 & 0.17 & 49.44 & 27.18 & 33.02 \\
6 & Acid volcanic & 83.87 & 0.06 & 4.40 & 9.44 & 0.02 & 0.17 & 0.24 & $<0.10$ & $<0.01$ & 0.01 & $\mathrm{ND}$ & $\mathrm{ND}$ & $\mathrm{ND}$ \\
7 & Calcified tuff & 20.54 & 0.13 & 2.30 & 1.34 & 0.52 & 2.55 & 34.70 & 2.06 & 0.75 & $<0.01$ & $\mathrm{NA}$ & $\mathrm{NA}$ & $\mathrm{NA}$ \\
8 & Tuff & 68.00 & 0.75 & 17.68 & 3.37 & 0.02 & 2.01 & 0.65 & 5.12 & 0.72 & 0.13 & 73.15 & 89.98 & 32.12 \\
9 & Tuff & 82.86 & 0.12 & 4.56 & 9.56 & 0.06 & 1.74 & 0.33 & 0.06 & 0.08 & 0.12 & 90.66 & 29.79 & 82.35 \\
10 & Tuff & 83.16 & 0.13 & 4.59 & 7.80 & 0.05 & 3.84 & 0.26 & 0.04 & 0.02 & 0.03 & 93.48 & 18.75 & 92.79 \\
11 & Acid volcanics & 80.84 & 0.16 & 12.79 & 0.54 & 0.02 & 0.38 & 0.18 & 5.04 & 0.24 & $<0.01$ & 70.08 & 96.70 & 10.62 \\
12 & Acid volcanics & 52.68 & 0.68 & 16.10 & 4.77 & 0.38 & 5.79 & 4.80 & 6.68 & 1.18 & 0.06 & 55.98 & 62.09 & 37.78 \\
13 & Acid volcanics & 76.09 & 0.22 & 13.51 & 2.01 & 0.03 & 1.75 & 0.37 & 1.33 & 4.35 & 0.04 & 69.07 & 93.89 & 78.21 \\
\hline Sl.no. & & Rock & $\mathrm{Ba}$ & $\mathrm{Cu}$ & $\mathrm{Ni}$ & $\mathrm{Rb}$ & $\mathrm{Cr}$ & $\mathrm{Sr}$ & $\mathrm{Th}$ & $\mathrm{Zr}$ & $\mathrm{Nb}$ & $\mathrm{Zn}$ & $\mathrm{Ce}$ & $\mathrm{Y}$ \\
\hline
\end{tabular}

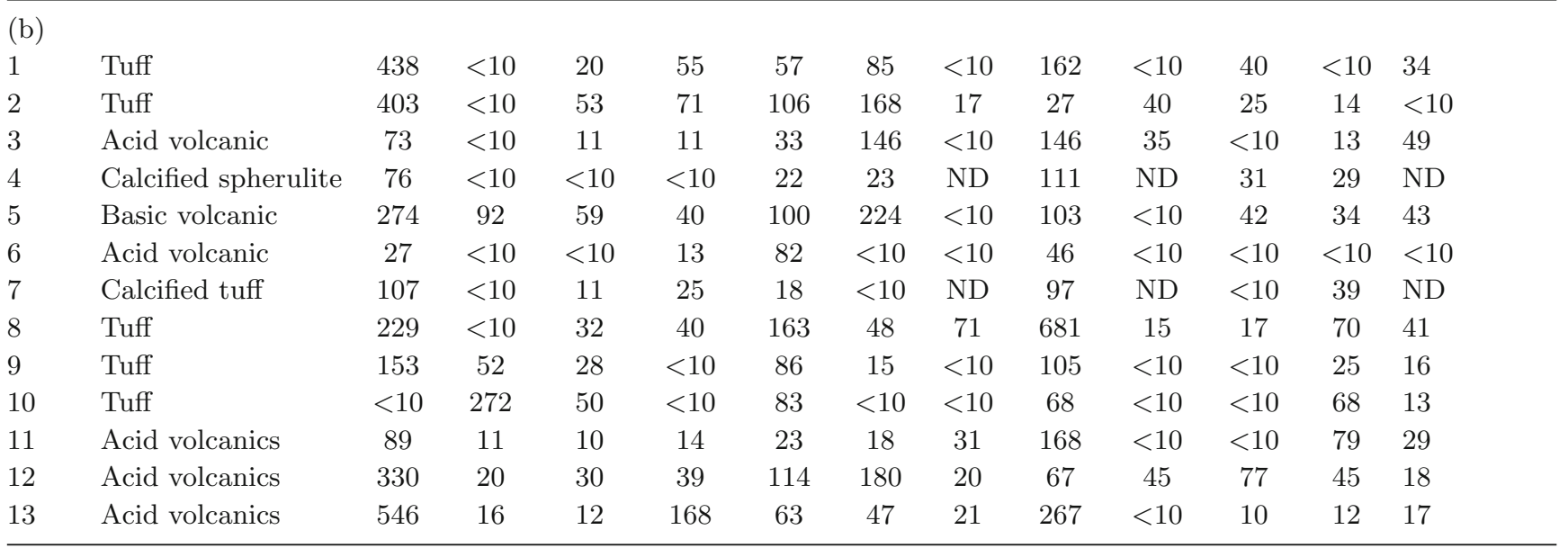

\section{Discussion and conclusion}

The widespread occurrence of basalt (basic) and rhyolite (acidic) without significant intermediate rock type is pointing to a bimodal volcanism.
Presence of bimodal volcanism is an indication of continental rift setting (Maria and Hermes 2001; Brewer et al. 2004) of the study area. Partial melting of the crust and mantle generates acidic and basaltic magma, respectively and generally 
Table 2. (a) Major element oxides of 13 selective samples of the study area and alteration indices. (b) Trace element data of 13 selective samples of the study area.

\begin{tabular}{|c|c|c|c|c|c|c|c|c|c|c|c|c|c|c|}
\hline S.No. & Rock & $\mathrm{SiO}_{2}$ & $\mathrm{TiO}_{2}$ & $\mathrm{Al}_{2} \mathrm{O}_{3}$ & $\mathrm{Fe}_{2} \mathrm{O}_{3}^{\mathrm{t}}$ & $\mathrm{MnO}$ & $\mathrm{MgO}$ & $\mathrm{CaO}$ & $\mathrm{Na}_{2} \mathrm{O}$ & $\mathrm{K}_{2} \mathrm{O}$ & $\mathrm{P}_{2} \mathrm{O}_{5}$ & CIA & FI & IAI \\
\hline \multicolumn{15}{|l|}{ (a) } \\
\hline 1 & Basic volcanic & 49.46 & 1.41 & 14.14 & 18.37 & 0.20 & 5.12 & 6.33 & 3.29 & 1.82 & 0.36 & 55.28 & 44.67 & 41.91 \\
\hline 2 & Basic volcanic & 48.95 & 2.19 & 12.90 & 13.84 & 0.16 & 6.99 & 8.50 & 2.70 & 1.50 & 0.19 & 50.39 & 33.07 & 43.12 \\
\hline 3 & Basic volcanic & 47.12 & 2.22 & 14.17 & 17.00 & 0.21 & 5.88 & 8.34 & 3.31 & 0.75 & 0.35 & 53.33 & 32.74 & 36.27 \\
\hline S.No. & Rock & $\mathrm{Ba}$ & $\mathrm{Cu}$ & $\mathrm{Ni}$ & $\mathrm{Rb}$ & $\mathrm{Cr}$ & $\mathrm{Sr}$ & $\mathrm{Th}$ & $\mathrm{Zr}$ & $\mathrm{Nb}$ & $\mathrm{Ce}$ & $\mathrm{Y}$ & & \\
\hline
\end{tabular}

\begin{tabular}{|c|c|c|c|c|c|c|c|c|c|c|c|}
\hline Basic volcanic & 672 & 53 & 37 & 44 & 32 & 217 & $<10$ & 137 & $<10$ & 38 & 20 \\
\hline Basic volcanic & 380 & 145 & 150 & 32 & 190 & 166 & $<10$ & 158 & $<10$ & 27 & 26 \\
\hline Basic volcanic & 244 & 183 & 60 & 166 & 146 & 210 & $<10$ & 190 & $<10$ & 40 & 32 \\
\hline
\end{tabular}
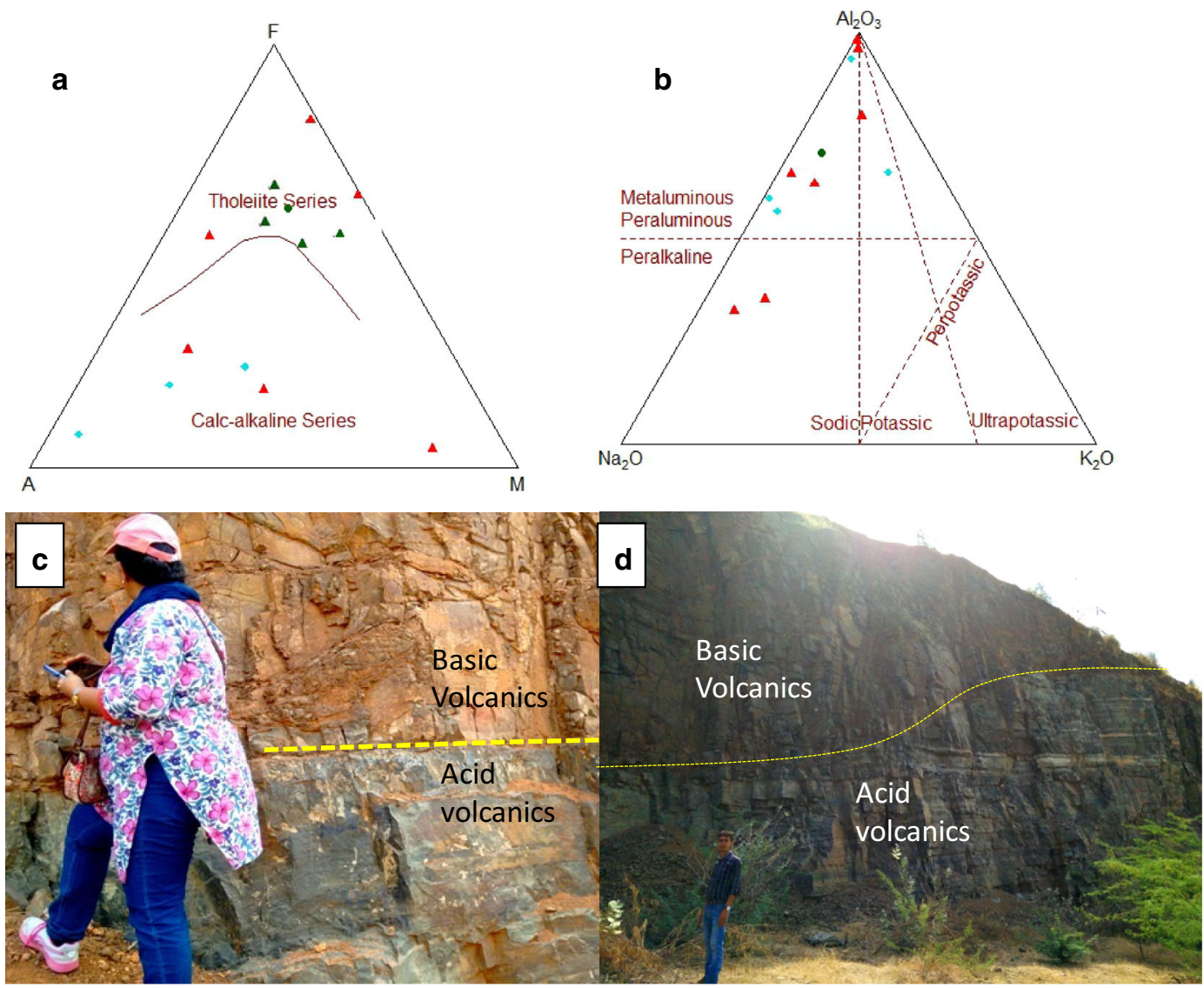

Figure 21. (a) Molar $\mathrm{Al}_{2} \mathrm{O}_{3}-\mathrm{K}_{2} \mathrm{O}-\mathrm{Na}_{2} \mathrm{O}$ (AFM) plot of the acid volcanics (cyan dots), tuff (red triangle) and basic volcanics (green triangle). (b) $\mathrm{Al}_{2} \mathrm{O}_{3}-\mathrm{K}_{2} \mathrm{O}-\mathrm{Na}_{2} \mathrm{O}$ plot showing peraluminous to metaluminous nature. (c) Felsic and mafic flows with bimodal association. (d) Road cutting section of bimodal volcanics with no cross cutting relationship.

rising basaltic magma partially melts continental crust, resulting in the dual occurrence of basalt and rhyolite (Tamura and Tatsumi 2002). Continental rifts produce a wide array of rocks that include alkalic basalt as well as alkaline and silicic rocks (Wilson 2007). Silicic rocks include rhyolite and rhyodacite, which occur in lava domes or as pyroclastic flow and ash fall deposits.
Various genetic processes involved in the formation of this volcanic sequence result in original textures which are classified into volcaniclastic and coherent categories. In the former type, particles of different shape and size are seen. Textures in volcaniclastic deposits encompass enormous variation, but, in general, are characterized by the presence of separate particles or fragments, 

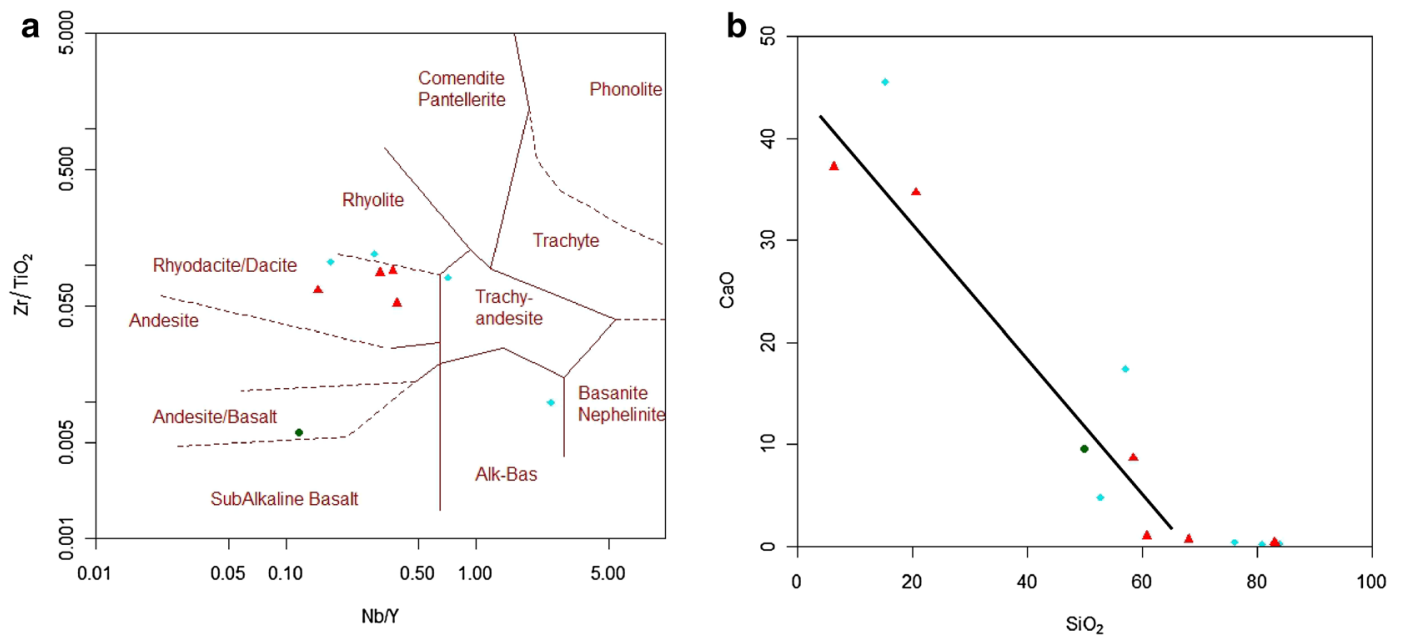

Figure 22. (a) $\mathrm{Nb} / \mathrm{Y}$ vs. $\mathrm{Zr} / \mathrm{TiO}_{2}$ diagram after Winchester and Floyd (1977). (b) CaO vs. $\mathrm{SiO}_{2}$ plot to support carbonatization observed in field.

Table 3. Correlation matrix of major element oxodes of table 1(a).

\begin{tabular}{|c|c|c|c|c|c|c|c|c|c|c|}
\hline & $\mathrm{SiO}_{2}$ & $\mathrm{TiO}_{2}$ & $\mathrm{Al}_{2} \mathrm{O}_{3}$ & $\mathrm{Fe}_{2} \mathrm{O}_{3}^{\mathrm{t}}$ & $\mathrm{MnO}$ & $\mathrm{MgO}$ & $\mathrm{CaO}$ & $\mathrm{Na}_{2} \mathrm{O}$ & $\mathrm{K}_{2} \mathrm{O}$ & $\mathrm{P}_{2} \mathrm{O}_{5}$ \\
\hline $\mathrm{SiO}_{2}$ & 1 & & & & & & & & & \\
\hline $\mathrm{TiO}_{2}$ & -0.15457 & 1 & & & & & & & & \\
\hline $\mathrm{Al}_{2} \mathrm{O}_{3}$ & 0.234459 & 0.550478 & 1 & & & & & & & \\
\hline $\mathrm{Fe}_{2} \mathrm{O}_{3}^{\mathrm{t}}$ & 0.274121 & 0.563723 & 0.095189 & 1 & & & & & & \\
\hline $\mathrm{MnO}$ & -0.45628 & -0.03913 & -0.15222 & -0.32015 & 1 & & & & & \\
\hline $\mathrm{MgO}$ & -0.18256 & 0.541973 & 0.402688 & 0.28359 & 0.404412 & 1 & & & & \\
\hline $\mathrm{CaO}$ & -0.91879 & -0.1349 & -0.53415 & -0.40846 & 0.434356 & -0.06042 & 1 & & & \\
\hline $\mathrm{Na}_{2} \mathrm{O}$ & -0.05099 & 0.26023 & 0.595486 & -0.3943 & 0.496139 & 0.341155 & -0.1206 & 1 & & \\
\hline $\mathrm{K}_{2} \mathrm{O}$ & 0.068303 & 0.184434 & 0.528014 & -0.00127 & -0.18114 & 0.136748 & -0.25166 & -0.02274 & 1 & \\
\hline $\mathrm{P}_{2} \mathrm{O}_{5}$ & -0.29243 & 0.59541 & 0.099907 & 0.322427 & -0.22603 & 0.174646 & 0.222722 & -0.10943 & -0.09832 & 1 \\
\hline
\end{tabular}
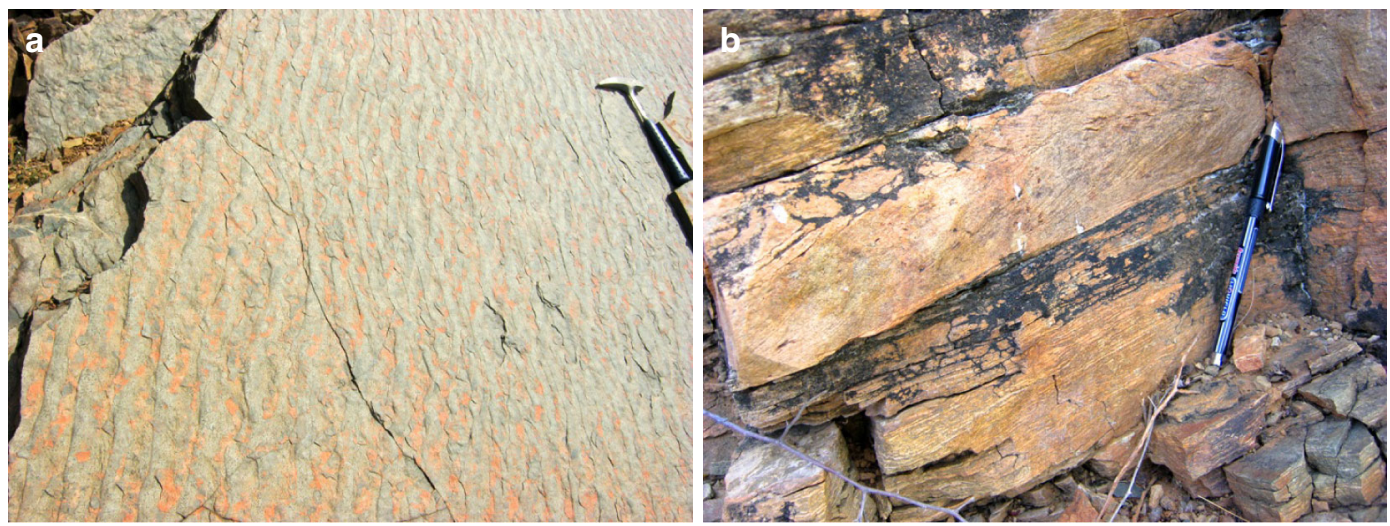

Figure 23. Volcaniclastic deposit with different types of depositional features like (a) ripples and (b) cross stratification indicative of transportation of volcanosedimentary materials.

mixtures of a few or many different particle shapes, sizes and types, or, in most of the cases presence of bedding or other sedimentary structures indicating particulate transport and deposition (figure 23). Coherent volcanic textures form from cooling and solidification of molten lava. Porphyritic texture, especially the presence of evenly distributed crystals is common. Aphyric, aphanitic and totally glassy textures are also coherent. Vesicles, flow foliations, spherulites and lithophysae are common in deposits with coherent textures. However, this is not independently diagnostic and also occur 
in volcaniclastic deposits. Coherent textures occur principally in lava flows and in intrusions. Presence of pumice at places is indicative of condition similar to the liquid foam generated when a bottle of pressurized soda is opened. The opening depressurizes the soda and enables dissolved carbon dioxide gas to escape or erupt through the opening. Presence of such features indicates that during an explosive eruption, volcanic gases dissolved in the liquid portion of magma also expand rapidly to create a foam or froth. In case of pumice, the liquid part of the froth quickly solidifies to glass around the glass bubbles.

It is known that the effusive eruption occurs when volatile contents are very low, or if volatiles are able to escape from the magma. The physical properties of magmas like composition, temperature, viscosity, volatile content, phenocryst content, etc., have a major influence on the internal textures, facies geometry and facies associations of lavas and syn-volcanic intrusions. Identification of some important textures and structures (e.g., porphyritic texture, spherulites, lithophysae and micropoikilitic texture, perlites, flow foliations, accretionary lapilli, columnar joints, graded bedding and planar as well as cross-stratification, vesicles, glass shards, etc.) has been helpful in different aspects of volcanological interpretations. The columnar joints, flow foliation, porphyritic texture indicate syn-volcanic intrusions. Spherulites, lithophysae and micropoikilitic texture are indicative of high-temperature devitrification of volcanic glass. Perlites indicate hydration of coherent volcanic glass. The accretionary lapilli are formed by subaerial explosive eruptions, but may be redeposited and reworked. Graded bedding are product of sedimentation from mass flows or suspension in contrary to the planar thin bedding formed by suspension or traction current deposition. However, cross strata are solely indicative of traction current deposition. It is also noteworthy that some components and textures like vesicles, pumice and scoria and glass shards are definitely of volcanic origin but not strongly diagnostic of particular condition of volcanic environment. In the field, primary volcaniclastic (pyroclastic, autoclastic) deposits are differentiated from reworked volcanogenic sedimentary deposits. However, it was very difficult task to differentiate resedimented, essentially syn-eruptive volcaniclastic deposits from reworked, post-eruptive volcaniclastic deposits without genetic connection with active volcanism.
At places mixtures of compositionally different volcanic particles with effects of weathering erosion and association with non-volcanic sedimentary facies can be observed which is indicative of transportation and resedimentation (figure 23a, b). Although, similar processes of transport and deposition operate in the formation of primary pyroclastic, syn-eruptive volcaniclastic and volcanogenic sedimentary deposits, the physical properties of volcaniclastic particles vary widely, and the interstitial fluid is gas and liquid mixture in case of syn-eruptive volcaniclastics (figure 24). The transport of volcaniclastic particles from the site of initial fragmentation to deposition mainly requires gravitational pull only. Finally, erosion of initial deposition involves time gap for weathering and transportation into final redepositional sites and this involves surface sedimentary transporting agents, such as wind, water or ice along with gravity.

It is known that the pyroclastic flows are product of mass flow in which clasts plus interstitial fluid (air, water, and volcanic gas) move together and interact. The pyroclastic surge deposits are related to traction in which clasts can move like bed load and the suspended load deposits are similar to fall deposits. Such volcanic terrain consists all of the variety of rock types. Thus, in this approach to describing, documenting and interpreting the rock types of the volcanic terrain, the facies concept has become very useful. The essence of facies analysis is the identification of distinctive characteristics that lend themselves to the interpretation of their origins, depositional processes and environments of deposition.

The angle of repose of cross-stratification for the volcaniclastics controls tractional sediment transport and surge type deposition. Structureless-tofaintly laminated epiclastic claystones or mudstones suggest settling out of suspension fall under very quiet condition. Where siltstone overlie shale, the basal surface of overlying siltstone beds are characterised by swellings ranging from slight bulges to highly irregular protuberance with diameter of a few centimetre. They are often showing some preferred orientation with respect to current direction like flute casts. Presence of these load casts indicates that water saturated muds were quickly buried by silty sand beds before dewatering could have taken place (figure 25).

Well-defined eutaxitic texture in the thick, massive, undeformed volcaniclastic deposit suggests welding and deposition by pyroclastic flow. However, for confirming about palaeoenvironment 

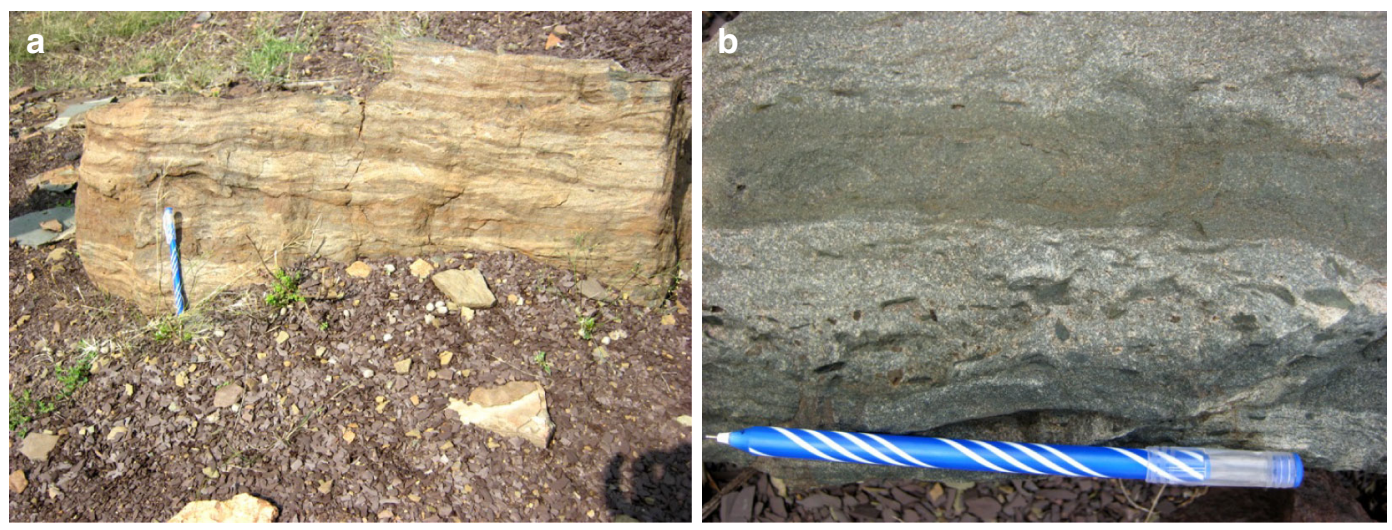

Figure 24. Syn-eruptive volcaniclastic transport features (Beduduru area) with no physical flow planes, but colour and composition bands possibly formed by interstitial fluid of gas and liquid mixture.
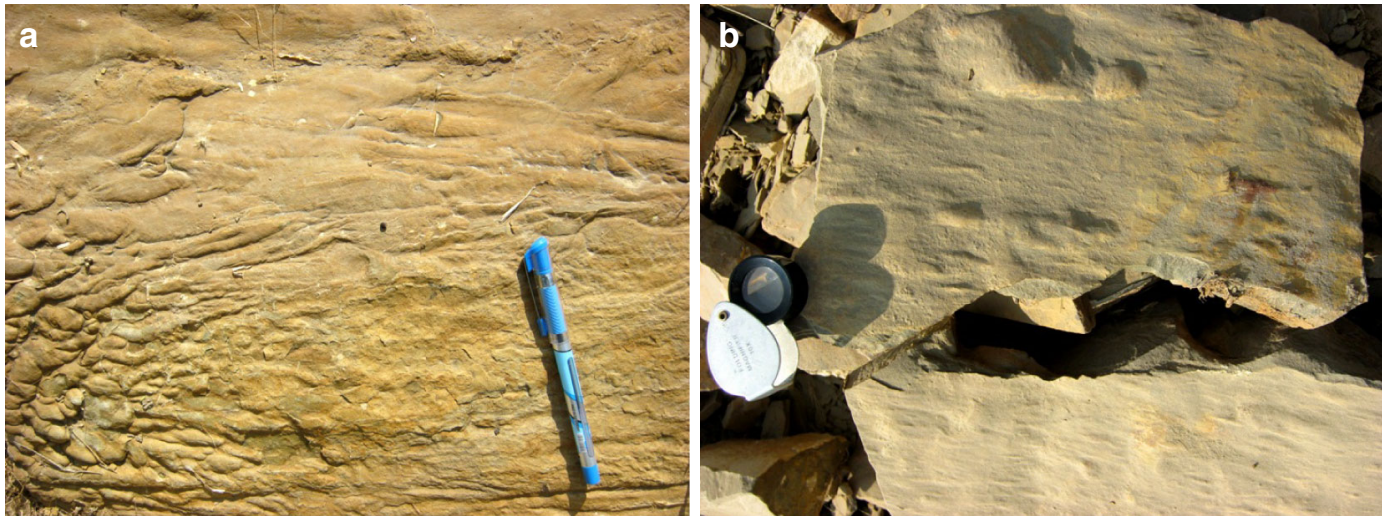

Figure 25. Load casts at the transported reworked tuffaceous shale-siltstone interbeds.

in this ancient terrain, significant associations of facies are a must. A single environmental indicator may indicate probability of more than one condition, hence in this paper a number of different features with paleoenvironmental significance are taken into consideration to conclude with sufficient degree of confidence. The carbonates are widespread and the precipitation of carbonates during and after rifting events in shallow marine environment of Cuddapah Basin is widely known fact (see Nagaraja Rao et al. 1987; Goswami et al. 2015). More specifically, after Vempalle Formation, lower Tadpatri Formation is devoid of much carbonates. However, the upper Tadpatri volcanics often show carbonatization at outcrop scale without any bed formation and these are not mappable. These carbonates are occupying the altered portions of felsic volcanics with devitrified glasses (figures 8, 9, 12), along with lithophysae and spherulites. Based on the present studies, it is concluded that volcanism in the study area was associated with rifting and shallow marine environmental condition. Rifting and associated volcanism as well as sedimentation must have taken place together.

\section{Acknowledgements}

The authors express their sincere gratitude to Shri L K Nanda, Honourable Director, AMD for encouragement and infrastructure support to publish the part of the assigned work. They are also thankful to the respected reviewers for the immensely helpful suggestions.

\section{References}

Best M G 2003 Igneous and metamorphic petrology; 2nd edn, Blackwell Science Ltd. ISBN 1-40510-588-7.

Bhaskar Rao Y J, Pantulu G V C, Damodar Reddy V and Gopalan K 1995 Time of early sedimentation and volcanism in the Proterozoic Cuddapah basin, south India: 
Evidence from Rb-Sr age of Pulivendla mafic sill; Geol. Soc. India Memoir 33 329-338.

Brewer T S, Ahall K, Menuge J F, Storey C D and Parrish R R 2004 Mesoproterozoic bimodal volcanism in SW Norway, evidence for recurring pre-Sveconorwegian continental margin tectonism; Precamb. Res. 134 249-273.

Burnham C W 1983 Deep submarine pyroclastic eruptions; Econ. Geol. Monograph 5 142-148.

Chatterjee N and Bhattacharji S 2001 Petrology, geochemistry and tectonic settings of the mafic dikes and sills associated with the evolution of the Proterozoic Cuddapah Basin of south India; J. Earth Syst. Sci. 110(4) 433-453.

Chakraborty K, Mukhopadhyay P K and Pankaj P 2016 Magmatism in Western Cuddapahs: The mafic sills and lava flows of Vempalle and Tadpatri Formations; J. Geol. Soc. India 87(6) 631-660.

Fisher R V 1960 Classification of volcanic breccias; Geol. Soc. Am. Bull. 71 973-982.

Gifkins C, Herrmann W and Large R R 2005 Altered volcanic rocks - A guide to description and interpretation; Hobart, Tasmania, Centre for Ore Deposit Research, University of Tasmania, 275p.

Goswami S, Bhattacharjee P, Bhagat S, Suresh Kumar and Zakaulla S 2015 Petrography of chert nodules in stromatolitic dolostone of Vempalle Formation, along Tummalapalle - Motnutalapalle, Cuddapah Basin, India, Indian J. Geosci. 69 13-24.

Geological Survey of India 1981 Explanatory brochure on Geological and Mineral Map of Cuddapah Basin, 121p.

Iddings J P 1887 The nature and origin of lithophysae and the lamination of acid lavas; Am. J. Sci. 33 36-45.

Irvine T N and Barager W R A 1971 A guide to the chemical classification of the common volcanic rocks; Canadian J. Earth Sci. 8 523-548.

Ishikawa Y, Sawaguchi T, Iwaya S and Horiuchi M 1976 Delineation of prospecting targets for Kuroko deposits based on modes of volcanism of underlying dacite and alteration halos; Mining Geol. 26 105-117 (in Japanese with English abstract).

Maria A and Hermes O D 2001 Volcanic rocks in the Narragansett Basin, southeastern New England: Petrology and significance to early basin formation; Am. J. Sci. 301286 312.

McLennan S M, Hemming S, McDanniel D K and Hanson G N 1993 Geochemical approaches to sedimentation, provenance and tectonics; In: Processes controlling the composition of clastic sediments (eds) Johnsson M J and Basu A, Geol. Soc. Am. Spec. Paper 285 21-40.

Nagaraja Rao B K, Rajurkar S T, Ramalingaswami G and Ravindra Babu B 1987 Stratigraphy, structure and evolution of Cuddapah basin; In: Purana basins of peninsular
India (ed.) Radhakrishna B P, Geol. Soc. India Memoir 6 $33-86$.

Nemeth K and Martin U 2007 Practical volcanology: Lecture notes for understanding volcanic rocks from field based studies; Geological Institute of Hungary, Budapest, ISBN 978-963-671-259-4.

Nesbitt H W and Young G M 1982 Early Proterozoic climates and plate motions inferred from major element chemistry of lutites; Nature 299 715-717.

Ramam P K and Murty V N 1997 Geology of Andhra Pradesh; Geological Society of India, Bangalore, $245 \mathrm{p}$.

Ross C S 1941 Origin and geometric form of chalcedonyfilled spherulites from Oregon; Am. Mineral. 26 $727-732$.

Sesha Sai V V 2011 Petrology and mineral chemistry of picrite sill from Peddakudala-Velpula area, in south western part of the Proterozoic Cuddapah Basin, Andhra Pradesh, India; In: Dyke swarms: Keys for geodynamic interpretation (ed.) Srivastava R K, Springer Verlag, Berlin Heidelberg, pp. 115-124, ISBN-978-3-642-12496-9.

Simpson E S W 1954 On the graphical representation of differentiation trends in igneous rocks; Geol. Magazine $\mathbf{9 1}$ 238-244.

Sparks R S J 1978a The dynamics of bubble formation and growth in magmas: A review and analysis; Volcanol. Geotherm. Res. 3 1-37.

Sparks R S J 1978b Gas release rates from pyroclastic flows: An assessment of the role of fluidisation in their emplacement; Bull. Volcanol. 41 1-9.

Tamura Y and Tatsumi Y 2002 Remelting of an andesitic crust as a possible origin for Rhyolitic magma in oceanic arcs: An example from the Izu-Bonin Arc; J. Petrol. 43 1029-1047.

Wenyan S and Xueyi Z 2013 Review of characteristics and genesis of lithophysae; Acta Geol. Sinica 87 57-59.

White J D L and Houghton B F 2006 Primary volcaniclastic rocks; Geology 34(8) 677-680.

Wilson M 2007 Igneous Petrogenesis; Chapman \& Hall, Springer, Dordrecht, The Netherlands, ISBN-13 978-0412-53310-5 (PB).

Williams H and McBirney A R 1979 Volcanology; Freeman, Cooper and Company, San Francisco, 397p.

Winchester J A and Floyd P A 1977 Geochemical discrimination of different magma series and their differentiation products using immobile elements; Chem. Geol. 20325 343.

Zachariah J K, Bhaskar Rao Y J, Srinivasan R and Gopalan $\mathrm{K} 1999 \mathrm{~Pb}, \mathrm{Sr}$, Nd isotope systematic of Uranium mineralized stromatolitic dolomites from the Proterozoic Cuddapah Supergroup, South India: Constraints on age and provenance; Chem. Geol. 162 49-64. 